\title{
Insurance company as dominant shareholder and financial performance in for-profit hospitals
}

\author{
Inmaculada Aguiar-Díaz, María Victoria Ruiz-Mallorquí \& Beatriz González \\ López-Valcárcel
}

To cite this article: Inmaculada Aguiar-Díaz, María Victoria Ruiz-Mallorquí \& Beatriz González López-Valcárcel (2018): Insurance company as dominant shareholder and financial performance in for-profit hospitals, Spanish Journal of Finance and Accounting / Revista Española de Financiación y Contabilidad, DOI: 10.1080/02102412.2018.1527474

To link to this article: https://doi.org/10.1080/02102412.2018.1527474

\section{册 Published online: 22 Oct 2018.}

\section{Submit your article to this journal 단}

Џ Article views: 21

View Crossmark data ¿ 


\title{
Insurance company as dominant shareholder and financial performance in for-profit hospitals
}

\author{
Inmaculada Aguiar-Díaz (10), María Victoria Ruiz-Mallorquí (10 ${ }^{a}$ \\ and Beatriz González López-Valcárcel (i) ${ }^{\mathrm{b}}$ \\ aFacultad de Economía, Empresa y Turismo, Departamento de Economía Financiera y Contabilidad, \\ Universidad de Las Palmas de Gran Canaria, Las Palmas de Gran Canaria, Spain; 'bFacultad de Economía, \\ Empresa y Turismo, Departamento de Métodos Cuantitativos en Economía y Gestión, Universidad de Las \\ Palmas de Gran Canaria, Las Palmas de Gran Canaria, Spain
}

\begin{abstract}
Ownership of hospitals matters with respect to financial performance, but the literature on this topic is scarce and largely focussed on for-profit versus non-for-profit hospitals. In contrast, this paper focusses on the for-profit hospital and, specifically, on the insurance companies as hospital dominant shareholders with respect to other types of shareholders. Arguments from the ownership and strategic management literatures are used from a theoretical point of view. Specifically, this paper analyses empirically the effects of insurance companies as controlling shareholders on the financial performance of unlisted, private, forprofit hospitals (179) in Spain from 2005 to 2012. The results show that the hospitals with insurance companies as controlling shareholders are less profitable and have a lower operating margin than do those controlled by banks, firms, or individuals/families. The lower performance might be explained by rent seeking by insurance companies as dominant shareholders because they could apply pressure to reduce the prices of the services provided by the hospitals to the insurers.
\end{abstract}

\section{La compañía de seguros como accionista domi- nante y la performance financiera de los hospitales privados}

\section{RESUMEN}

La propiedad de los hospitales influye en su rendimiento financiero, si bien la literatura sobre este aspecto es escasa y se centra principalmente en las diferencias entre los hospitales lucrativos y no lucrativos. Por el contrario, este trabajo se centra exclusivamente en los hospitales con fines de lucro, y específicamente, en las compañías de seguros como accionistas dominantes del hospital con respecto a otros tipos de accionistas. Los argumentos teóricos se basan en la literatura de propiedad, así como, en la de gestión estratégica. En concreto, este trabajo analiza empíricamente los efectos de las compañías de seguros como

\section{ARTICLE HISTORY}

Received 28 November 2017

Accepted 19 September 2018

\section{KEYWORDS}

Hospital; insurance company; ownership; performance; tunnelling; vertical integration

JEL CLASSIFICATION

$\mathrm{G} 32 ; 113$

CONTACT María Victoria Ruiz-Mallorquí $\otimes$ victoria.ruiz@ulpgc.es @ Departamento de Economía Financiera y Contabilidad, Facultad de Economía, Empresa y Turismo, Universidad de Las Palmas de Gran Canaria, 35017 Las Palmas de Gran Canaria 
accionistas de control sobre el rendimiento financiero de los hospitales privados sin fines de lucro (179) en España entre 2005 y 2012. Los resultados muestran que los hospitales con compañías de seguros como accionistas controladores son menos rentables y tienen un margen operativo menor que aquellos controlados por bancos, empresas o individuos/familias. El menor rendimiento podría explicarse por la búsqueda de rentas por parte de las compañías de seguros como accionistas dominantes, ya que podrían ejercer presión para reducir los precios de los servicios prestados por los hospitales a las aseguradoras.

\section{Introduction}

As it is well known, corporate governance is the system by which companies are directed and controlled. Undoubtedly, one of the most important control mechanisms within the corporate governance of companies is their ownership structure. In this sense, the extensive literature on the ownership structure analyses the impact of the same on performance and on corporate decisions, considering aspects such as the distribution of ownership of shares, the existence of pyramidal structures, the presence of large shareholders or the nature of them, among others. In addition, the ownership structure of private enterprises is one of the main determinants of their contractual relationships and has a decisive influence on management behaviour. Ownership is therefore an important factor to consider in the study of any economic sector in which there is private capital. Such is true in the hospital services sector. Moreover, the study of the ownership structure of companies not publicly traded must consider the fact that the lack of a market constrains the sale of shares in these businesses. Thus, share ownership tends to be concentrated in a small number of holders. Among the different types of shareholders who can play a major role in corporate decisions (individuals, families, financial and non-financial institutions) are those of an institutional nature (e.g. Faccio \& Lang, 2002; La Porta, Lopez-de-Silanes, \& Shleifer, 1999), particularly banks, insurance companies, mutual funds, pension funds, and venture capital funds. Many studies have analysed the effect of the presence of these controlling shareholders on the performance of the businesses they control, particularly the fact that these investors should not be considered a homogeneous group because some institutional investors might have business relationships with the owned firms, whereas others do not. However, whereas various studies consider the role of institutional investors such as banks (De Andrés et al. 2010; Gorton \& Smith, 2000; Santos \& Rumble, 2006) or mutual funds (Dai, 2007; Nain \& Yao, 2013), studies that examine the role of insurance companies as shareholders are scarce.

The case of hospitals is appealing because of their specific characteristics (uncertainty of demand, asymmetries of information, difficulties in measuring perceived quality) and above all because of the existence of a third payer for most of the patients. That third payer can be an insurance company - which can be also the owner of the hospital, in a vertically integrated business - the public National Health System (hereafter NHS) or private out-of-pocket funds. 
This article analyses the effects of the type of controlling shareholder, and in particular of insurance companies, on the financial performance of unlisted for-profit hospitals in Spain. Private for-profit hospitals have received little attention in the health economics literature, although a majority of researchers consider ownership an important explanatory factor for hospital performance (Lachmann, Trapp, \& Wenger, 2016; Shen, Eggleston, Lau, \& Schmid, 2007). This study represents, as far as we know, the first on this subject. Spain is an interesting country for a case study because, despite the universal health system, there is a high prevalence of complementary private health insurances $(26 \%$ of households in Spain have private health insurance). ${ }^{1}$ In 2012, there were 789 hospitals in Spain, of which 309 were private for-profit institutions, in which ownership is increasingly concentrated. The dynamics of creation and destruction of private hospital businesses closely depends upon the institutional context and regulatory incentives, as Jeurissen (2010) describes in detail for several developed countries.

From a theoretical perspective, arguments from the ownership and strategic management literatures are presented. Following the former, a dual hypothesis is proposed that suggests that the performance in hospitals controlled by an insurance company depends upon the benefit of the business ties being greater or less than the investment value loss produced when there is rent seeking by the insurance company. The latter situation allows presenting the insurer-hospital relationship as a vertical integration strategy, which could produce greater revenues derived from the increase in the number of patients that are insured. However, the attention to a greater number of patients also entails higher costs. Consequently, the operating margin depends upon what effect prevails.

The present study analyses an unbalanced panel of 179 for-profit hospitals registered in the National Hospital Catalogue in the period 2005-2012 (1.009 firm year observations), for which there was information on both ownership and financial return in the SABI database. None of these hospitals as such is publicly traded on stock exchanges. We registered data for each hospital on shareholders and financial performance for the period of study. Approximately $80 \%$ of the hospital-year observations have an identified dominant shareholder (owning more than 50\%). Among them, the dominant shareholder is an insurance company the $20 \%$ of the cases. The average ownership by dominant insurance companies is approximately $87 \%$, and in more than one-half of the cases, the insurance company owns $100 \%$ of the hospital. Most of the private general hospitals in Spain have an agreement (called concierto) with the public National Health Service (NHS) to diagnose and treat specific patients covered by the universal public insurance.

The results indicate that hospitals, whose principal shareholders are insurance companies, are less profitable and have a lower operating margin than do those whose principal shareholders were banks, businesses, individuals or families. The lower performance might be explained by rent seeking by insurance companies as dominant shareholders to the extent that behaviour reduces the prices of the services provided by the hospitals to the insurers. Insurance companies that have business relationships with the hospitals they control would transfer resources upwards from the hospital.

According to these results, the main contribution of the work would be related to the ownership and corporate governance literature. In this way, it is demonstrated how the identity of the dominant shareholders of the hospitals analysed is relevant because their 
particular interests are affecting the performance of hospitals. Specifically, the uniqueness of the relationships between insurance companies as dominant shareholders and hospitals provides a unique scenario. This offers the opportunity to observe the extent to which this type of shareholders with business relationships with the investee leads to a conflict of interests that results in a deterioration in the performance of the controlled company, despite being the dominant shareholder (even maintaining $100 \%$ of the property). In addition, in this case a third subject appears, the insured, which is an exclusive feature of the relationship between insurance property-hospital. In other cases, in which the induced business may occur, such as between a banking entity and the company in which it participates as a client, no other figure appears in the relationship. In a second place, the results also support the arguments regarding how vertical integration between hospitals and insurance companies conditions the costs and prices of the services provided.

The rest of the paper is structured as follows: the second part briefly presents the main aspects of the hospital sector in Spain. The third presents theoretical arguments about the relationship between ownership and performance, with special reference to institutions as investors and insurance companies in particular. The fourth part treats methodological aspects, and the fifth, the results. The sixth and final part presents the main conclusions and implications.

\section{For-profit hospital sector in Spain}

In Spain, the NHS, funded from taxes and predominantly operating within the public sector, that is, in public healthcare centres, provides universal primary and specialised healthcare to the population. Provision is free of charge at the point of delivery with the exception of the pharmaceuticals. Regional governments are responsible for organisation and delivery of health services within their territory, and they own the public regional hospitals.

Despite the universal coverage, $26 \%$ of households in Spain have complementary or supplementary private health insurance that covers some of the uncovered services such as dental care - and/or allows patients to bypass the long waiting lists in the public network. Additionally, civil servants can choose among commercial health insurance companies or the public provider (called National Institute of Social Security).

The basic difference between Spain's hospitals and those in other countries is that in Spain, private hospitals are largely for-profit. According to the National Hospital Catalogue, $31.5 \%$ of the general hospitals were private and for-profit in 2013 (18.5\% of the total beds, much higher than in the UK (5\%) and similar to Germany (Jeurissen, 2010)).

In the last decade, the private hospital sector has undergone and continues to undergo an intense process of concentration and change of ownership and has created organisations, occasionally in the form of foundations, that have been quite vocal in the defence of their interests. In the period under study from 2005 to 2012, the number of for-profit hospitals increased from 311 in 2005 to 322 in 2008 and then declined by 2012 to 304. In the boom years (2005-2007), new private hospitals were created, and in the economic crisis (2008-2012), there was a process of consolidation.

Private health spending in 2012 was $28.3 \%$ of total health expenditures. It increased in the years of economic crisis, in contrast with public health spending, which was cut back (Ministry of Health, Social Services and Equality, MSSSI, 2014). However, the role 
of private healthcare providers is much more substantial than these spending figures would suggest, because the services provided to those insured by the NHS through accords or indirect management contracts are counted as public expenditures.

Barrubés and Mellado (2011) noted the importance of the role of the insurance companies in the Spanish hospital sector. The main business models among private hospitals, according to these authors, are hospital groups connected to an insurance firm, independent hospital groups not owned by insurers, and individual independent clinics that neither belong to a hospital group nor are owned by an insurance company. One factor that might be driving the consolidation of the private hospitals is the need to negotiate more effectively with the insurance companies. An indication of this need is that, as reported by Barrubés and Mellado (2011), 62.3\% of the income of Spanish for-profit private clinics with hospitalisation comes from accords with insurance companies and cooperatives.

For the health insurance sector in Spain, the volume of premiums collected in $2012(6,806$ million Euros) was 51.6\% greater than in 2005. In 2012, health assistance represented $77.8 \%$ of the total insurance premiums in Spain (87\% in 2005) (Fundación Mapfre, 2012, p. 201).

\section{Ownership and hospital financial performance: conceptual framework and hypotheses}

From a theoretical point of view, the relationship between ownership and performance in the presence of business relationships between the dominant shareholder and the controlled firm could be analysed from the ownership literature, as a control mechanism of corporate governance, and the strategic management approach specifically as a vertical integration strategy.

\subsection{Insurance-hospital relationship from the ownership perspective}

The relationship of ownership and performance in the hospital is going to be approached with consideration of the roles of different types of shareholders and of whether they can be considered majority or dominant investors in the ownership of the firms. When there is a majority or dominant shareholder, much depends upon its type. As Cuervo (2002) holds, the qualitative aspects of what is known as the core shareholders' can be especially influential in the behaviour and goals of the enterprise. Thus, Thomsen and Pedersen (2000, p. 689) argue that the identity of the owner is an important aspect of the ownership structure because, 'Whereas ownership concentration measures the power of the shareholders to influence management, the identity of the owners has implications for their objectives and how they exercise their power...' These observations are supported by a number of studies on the types of dominant shareholders (families, businesses, financial institutions, and the state) and their differential effects on enterprise performance (e.g. Anderson \& Reeb, 2003; Gorton \& Smith, 2000; Villalonga \& Amit, 2006).

Institutional investors include a wide range of institutions, largely financial, that include banks, insurance companies, mutual funds, pension funds, and venture capital funds. In the ownership literature, insurance companies fall in the category of institutional owners that can play a prominent role in corporate decisions (e.g. Faccio \& Lang, 
2002; La Porta et al., 1999). In the case of hospitals, the roles of the institutional investors and, specifically, of the insurance companies become relevant.

Many studies examine the types of institutional investors and point to the differences between them (Almazan, Hartzell, \& Starks, 2005; Borokhovich, Brunarski, Harman, \& Parrino, 2006; Brickley, Lease, \& Smith, 1988; Chen, Harford, \& Li, 2007; Cornett, Marcus, Saunders, \& Tehranian, 2007; De la Hoz \& Pombo, 2016; Duggal \& Millar, 1994; Elyasiani \& Jia, 2010; Ferreira \& Matos, 2008; Gillan \& Starks, 2003; Ruiz \& Santana, 2009, 2011). They distinguish between two main groups. One is of 'pressuresensitive investors,' those who do or might do business with the enterprises whose stock they hold; these investors are fundamentally banks and insurance companies. The second group is of 'pressure-insensitive or -resistant investors,' which includes institutions that do not do business with the enterprises of which they are shareholders; these investors tend to be mutual and pension funds. ${ }^{2}$

The effect on an institutional investor with respect to enterprise performance, then, is likely to depend upon their type and, more specifically, on whether the investor maintains business dealings with the firms in question. When the controlling shareholders are institutions, the potential for extraction of private gain is particularly related to the generation of business by these institutions by taking advantage of their influence on the enterprises (Barclay, Holderness, \& Pontiff, 1993; Bona, Pérez, \& Santana, 2013; Gorton \& Smith, 2000; Hoshi, Kashyap, \& Scharfstem, 1993; Ruiz \& Santana, 2011; Weinstein \& Yafeh, 1998). In the case of hospitals, insurance companies are institutional investors that can extract private gain from a dominant shareholder position. More specifically in the case of private hospitals, business relationships with insurance companies as controlling shareholders take the form of medical insurance offered by the companies that can be an important source of hospital revenue (Klenk, 2011). However, the insurance company might be interested in negotiating low prices to pay for the hospital services to obtain a benefit from the difference between the premiums and the healthcare expenses. Additionally, the insurance company can lower premiums to gain market share in the health insurance market, and they compensate for those revenue losses by lowering prices paid to hospital providers.

Although there is an absence of previous studies analysing the relationship between ownership and performance of private hospitals, there are some studies that have considered the ownership of insurance companies or others institutional owners who have business ties with the controlled firms. In this sense, Rose (2007) found for Denmark that ownership by insurance companies improved the performance of publicly traded companies. In the same line, Elyasiani and Jia (2010) find that pressuresensitive have a positive effect on publicly traded US companies. However, authors like Bhattacharya and Graham (2007) for Finland or Ruiz and Santana (2011) for Spain found that institutions that had business relationships with firms in which they were shareholders negatively affected the firm's performance.

This behaviour by the insurance companies as dominant shareholders would respond to what is known in the literature of ownership as tunnelling practices. 'Tunnelling is the diversion of corporate resources from the corporation (or its minority shareholders) to the controlling shareholder' (Johnson, La Porta, Lopez-de-Silanes, \& Shleifer, 2000, p 26). As these authors state, tunnelling can cause the transfer of 
resources through different mechanisms, such as contracts involving transfer pricing advantageous to the controlling shareholder ${ }^{3}$ or by manipulating transfer prices (Bertrand, Mehta, \& Mullainathan, 2002). Tunnelling practices are most evident in countries with less legal protection of investors and groups of interconnected companies, particularly if organised into pyramids (Friedman, Johnson, \& Mitton, 2003). As Bae, Kang, and Kim (2002) say, owners of groups of companies practising tunnelling usually focus more on their own wealth and act for their own benefit. Thus, Wang and Zhou $(2006)^{4}$ find a tunnelling negative effect on the performance of the companies controlled, with a sample of Chinese listed companies. Similarly, an international study to measure tunnelling (Gugler, 2013) concludes that income transfers occur from investees to their parent firms.

Thus, the ownership literature asserts that the presence of controlling shareholders with an important role in enterprises has traditionally been explained by their extraction of private gain, gain that they do not share with minority shareholders (e.g. Claessens, Djankov, Fan, \& Lang, 2002; López de Foronda, López-Iturriaga, \& Santamaría-Mariscal, 2007; Shliefer and Vishny 1997; Villalonga \& Amit, 2006). However, in the presence of a high ownership concentration, which is the usual case for unlisted firms, the incentives for expropriation from the dominant institutional investors using their business relationships with the subsidiary companies are lower. That situation exists because the increase in the wealth of the dominant owner resulting from its business relationships with the subsidiary company could be compensated for with 'the costs that this shareholder would support when the effects of that behaviour revert to the company with the opposite sign, causing a reduction of the firm value' (Bona et al., 2013, p. 376).

Thus, with the aim of gaining market share in the health insurance market, the insurance companies try to reduce the premiums charged by insurance policies. To achieve this goal, the insurance company will try to adjust the prices paid for services to hospitals in which its presence is dominant. This practice has two opposite effects for the insurance company. On the one hand, the imposition of a reduced price rate on hospitals allows the insurance company to obtain a lower cost for the services to its insured (benefit via business ties, tunnelling effect). On the other hand, this fact results in lower revenues for rendered services, which, ceteris paribus, reduces the hospital performance. At the same time, the lower performance reduces the value of the shares of controlled firm (the hospitals). A reduction in the value of these shares held by insurance companies represents a loss that the insurer company must support (value effect). Therefore, the insurance firm only performs those practices of price reduction for the services provided by the hospitals, when the benefits from the business ties (increase in income from insurance premiums) compensate it for the value reduction as hospital shareholder (derived from a lower performance of the hospital). On the contrary, if the loss of value of the shares is higher than the income obtained by the collection of insurance premiums, the insurance company will not reduce the prices for the services provided by the hospitals to their insured, in which case it is possible that, ceteris paribus, due to a greater number of insured patients, the hospital controlled by an insurance company presents a higher performance than those controlled by other types of entities.

Therefore, according to the above arguments, the effect of the presence of a dominant insurer on the performance of the hospitals it controls is unclear; it could 
be positive or negative depending upon the intensity of the opposite influencing factors. Consequently, the first hypothesis is presented in the following terms:

H1. Tunnelling versus value effects. The rent seeking by the insurance company will depend upon whether the benefit from the business ties via price reduction does or does not compensate for the loss of its investment value as dominant hospital shareholder.

H1a. Lower hospital profitability in the hospitals controlled by an insurance company against the rest of the hospitals shows tunnelling effect predominance.

H1b. Greater hospital profitability in the hospitals controlled by an insurance company against the rest of the hospitals shows value effect predominance.

\subsection{Vertical integration in the insurance-hospital relationship}

The ownership relationship between insurance companies and the hospitals can be analysed from a vertical integration perspective. ${ }^{5}$ The relevance of vertical integration in healthcare has been considered in previous works (e.g. Robinson \& Casalino, 1996). According to Tirole (1989), the firm is vertically integrated if it controls (direct or indirectly) all of the decisions adopted by the firms belonging to the structure. Thus, the impossibility of considering all of the contingencies, together with the existence of information asymmetries, makes the contracts incomplete, which can lead to opportunistic behaviour. Another important view is proposed by the transaction cost theory (Klein, Crawford, \& Alchian, 1978). From this perspective, vertical integration reduces the costs of negotiation and supervision of the contracts between insurance and providers. Baranes and Bardey (2015) assert that the vertical integration is often presented as an efficient remedy for reducing or containing increasing health care expenditures because it allows insurers to reduce providers' moral hazard and transaction costs and negotiate lower prices with health care providers (Cutler, McClellan, \& Newhouse, 2000).

Vertical integration has advantages and disadvantages for both the insurer company and the hospitals. Among the advantages for the insurance company is the possibility of setting the price of health services and reducing overutilisation of services by patients. This can be achieved through control over doctors and, consequently, decreasing the induced ${ }^{6}$ demand by the physician through control of expenses. The main disadvantage for the insurance company is the fixed cost of the investment to acquire the dominant shareholder position of the hospital.

Hospitals with an insurance company as the dominant shareholder have the main advantage of having a regular source of patients guaranteed, allowing them to operate near their maximum capacity and therefore increase their revenues. According to Barrubes and Mellado (2011), the increase in private hospital invoicing has been a consequence of the growth in the number of patients - specifically, patients from the private insurance sector, who represent $62.3 \%$ of the business volume. 7 This fact gives an important power of negotiation to insurance companies, which is reinforced by the concentration process 
that has occurred in recent years. However, the income from services provided to insured patients is usually lower than that obtained from private patients due to the pressures of insurance companies to reduce prices (Balakrishnan, Eldenburg, Krishnan, \& Soderstrom, 2010; Hsu, 2011). Thus, if the insurance company controls those hospitals due to its position as dominant investor, it can pay low prices. Gal-Or (1997) finds that when a health service provider maintains an exclusive relationship with an insurer, it can accept a smaller payment for a large volume of patients, which benefits the insurance company.

In addition, to reduce the prices of medical services, insurers pressure hospitals to reduce costs (Balakrishnan et al., 2010; Ding, 2014; Hsu, 2011). According to Robinson (1999), vertical integration in health services is a strategy of last resort due to the inability to control medical spending through other channels. This point could explain why some hospitals pursue a low-cost strategy rather than improving service quality (Cardinaels \& Soderstrom, 2013). Ciliberto and Dranove (2006) indicate that when an insurance company intervenes in the hospital-patient relationship, hospitals have two options for reducing prices: increasing efficiency and reducing costs, or increasing bargaining power vis-à-vis insurers. Such bargaining is difficult because the power of insurers has increased significantly due to the use of prospective payment schemes; however, due to the competition among service providers (e.g. Burns, 1990; Cardinaels \& Soderstrom, 2013), hospitals should be reducing costs. This change is especially relevant in Spain because the important weight of private insurance in hospital revenues gives greater negotiation power to insurance companies (Barrubés \& Mellado, 2011). Thus, cost efficiency occurs when a hospital chooses a costminimising input mix, given input prices (Tienman et al 2012), ${ }^{8}$ and set forth to address cost pressures from insurance payers by increasing productive efficiency (Ding, 2014).

In summary, from the vertical integration point of view, the position of the insurance company as dominant shareholder allows reduction of the health service costs that a hospital passes to its insurer, just as with other types of costs, such as those relative to induced demand. For hospitals, this type of relationships represents a likely increase in the income derived from the increase in the number of patients and a potential reduction of costs. The joint effect of these factors in the operating margin depends upon which of them prevails. Thus, under the conditions that the negotiation power allows the insurance company to reduce the prices that it pays to the hospital and that an increase in the number of insured patients is produced, it is expected that the revenue will increase. However, service provision to a greater number of patients supposes incurring corresponding expenses. Consequently, the hospital result depends upon whether expense control occurs and expense efficiency improves under the pressure of the insurance company. Alternatively, a reduction in the operating margin will occur. Based on these arguments, the following hypotheses are presented:

H2. Activity versus price in vertically integrated hospitals. In hospitals that are vertically integrated with an insurance company, there is an increase in the revenues derived from the growth in the number of patients, which, ceteris paribus, raises the operating margin. Conversely, the revenues per patient can be lower due to the low prices that the insurance company imposes.

H2a. Vertically integrated hospitals show higher revenues compared with other hospitals due to an activity effect. 
H2b. Vertically integrated hospitals show lower revenues compared with other hospitals due to a reduction in prices.

H3. Cost efficiency in vertically integrated hospitals. In the hospitals that are vertically integrated with an insurance company, there is an increase in the expenses derived from the growth in the number of patients and at the same time a decrease in the expenses derived from the pressure of the insurance company.

H3a. Hospitals that are vertically integrated with an insurance company show a greater expense efficiency compared with other types of hospitals.

H3b. Hospitals that are vertically integrated with an insurance company show a lower expense efficiency compared with other types of hospitals.

Finally, the impact of increased activity derived from the relationship between the hospital and the insurance company in the margin depends, in turns, on the effect on revenues and costs, so it is unpredictable. Therefore, the fourth hypothesis is stated in the following terms:

H4. Vertical integration insurance-hospital and operating margin. The effect of the vertical integration insurance-hospital in the operating margin is unpredictable, because it depends on the joint effect on revenues and costs, which in turns are not predictable.

\section{Methods}

\subsection{Sample and data sources}

This study uses two entwined data groups, the National Hospital Catalogue (NHC) and the SABI database maintained by Bureau van Dick. The NHC is a public and official register of all accredited hospitals in Spain, updated annually by the Ministry of Health, which contains for each hospital its size, technology, type of ownership, specialty and whether it has accords with the NHS. The SABI database provides financial data from the annual accounts of the hospitals and historical information on the shareholders of each hospital.

We analysed the annual data for the period from 2005 to 2012, choosing this period because of the availability in the database of historical information on shareholders. We selected for study all hospitals in the national register that were private and for-profit, including those public hospitals in the Valencia Autonomous Region that had been ceded to for-profit private management.

To ascertain the ownership of the hospitals, we examined them one by one in the SABI database, a task complicated by changes in ownership and in how the database classified the businesses. Once each hospital was located in the SABI data, we eliminated from the sample those for which the financial and/or ownership information was not available. The initial sample is composed of 348 hospitals and 2.540 
observations (hospital-year). The final sample comprises an unbalanced panel of 1009 observations corresponding to 179 hospitals, an average of 5.6 observations per hospital.

\subsubsection{Variables}

4.1.1.1. Dependent variables: financial performance and its components. As in previous studies on hospital financial performance, ${ }^{9}$ and according to our hypotheses, we here considered different measures of financial performance, all based on accounting information. We used three dependent variables of financial performance, two of profitability and the operating margin. We assume that profitability is the main objective of the hospitals in our sample due to its private nature (Eldenburg, Hermalin, Weisbach, \& Wosinska, 2004, Caers et al. 2006). Specifically, we measure profitability through return on assets (ROA), calculated as the quotient between earnings before interest and taxes (EBIT) divided by total assets, and $R O A$ A_EBITDA similar to ROA, changing the numerator to EBITDA (earnings before interest, taxes and depreciations assets). Operating margin (OP_Margin) is calculated as the quotient between EBITDA and operating revenues. Two components of the operating margin are also individually considered, the ratio of operating revenues over total assets $(\boldsymbol{R E} \boldsymbol{V})$ and the cost efficiency $\left(\boldsymbol{C} \_\boldsymbol{E F I}\right){ }^{10}$ proxied by the quotient between the operating expenses (includes all expenses related to hospital operations, such as employee salaries and benefits, medical supplies, and depreciation) and total assets.

4.1.1.2. Explanatory variables: ownership. In keeping with our hypothesis, the chief explanatory variable is hospital ownership. This variable has been considered in a number of studies of the financial performance of hospitals. ${ }^{11}$ However, almost all have compared for-profit and non-profit hospitals, whereas we examine here only forprofit hospitals and make the comparison in terms of concentration or dispersal of ownership and above all the type of dominant shareholder.

Analysis of the ownership structure requires setting a threshold for the percentage of stock ownership that determines the existence and the identification of a controlling shareholder. For our purposes, we considered a shareholder dominant who owned more than $50 \%$ of shares, thereby assuring that no other shareholder has effective control. This criterion is especially germane for unlisted businesses such as ours because this percentage would permit the shareholder to make decisions in the absence of a market for trading. We differentiate here between having and not having a controlling shareholder - and if there is one, we identify its type. The dummy variable NoContSh takes the value 1 if the hospital has no controlling shareholder (i.e. with more than $50 \%$ of the shares) and zero otherwise. When there is a controlling shareholder, we then classify its type. Here, as we address hospitals, the presence of insurance companies in the enterprise ownership is especially relevant because they combine shareholding and consumption of health services through their policyholders. Based on the types of shareholders identified in the SABI database, we have created the following dichotomous variables: Insurers, Enterprises, Banks, and Families, which take the value 1 if the dominant shareholder is an insurance company, a non-financial business, a bank or financial entity, or an individual or family, respectively. 
According to hypothesis $\mathrm{H} 1 \mathrm{a}(\mathrm{H} 1 \mathrm{~b})$, we expect a negative (positive) relationship between the presence of an insurance company as dominant shareholder and profitability (ROA and ROA_EBITDA). The hypothesis $\mathrm{H} 2 \mathrm{a}$ (H2b) predicts a positive (negative) relationship between the presence of an insurance company as dominant shareholder and hospital revenues $(\mathrm{Rev})$, whereas $\mathrm{H} 3 \mathrm{a}(\mathrm{H} 3 \mathrm{~b})$ predicts a negative (positive) relationship between the presence of an insurance company as dominant shareholder and cost efficiency (Cost_Efi). The sign of fourth hypothesis can be positive or negative.

4.1.1.3. Control variables. First, we considered whether there was an ongoing 'concierto' or collaboration accord between a private hospital and the public health system. As we have indicated, this practice is habitual in Spain; patients can be treated in private hospitals at the expense of the public health system. This practice greatly increases the number of potential patients and thereby the income of private hospitals. Because authority in health matters has been transferred to Spain's autonomous regions, there are differences from region to region in the nature of the accords. The variable Con-SS takes the value 1 if the hospital has an ongoing accord with the Spanish National Health Systems. Together with the concierto with the National Health System, in some autonomous communities, there is a hospital network for public use comprising the public hospitals. In Catalonia, for instance, the Instituto Catalán de Salud and other, private ones, both operate under similar conditions. Finally, it is necessary to separate out public hospitals operating under private management concessions because these too treat patients from the public health system. To distinguish between these situations, we created two other dichotomous variables: Con-Cat, which takes the value 1 if the hospital has an ongoing accord with the Autonomous Community of Catalonia, and Concession, which takes the value 1 if the hospital is operated as a management concession.

Furthermore, as with previous studies on hospital financial performance, we have used as control variables leverage, growth opportunities (Growth_Op), proxy by intangible over total assets, size, represented by the number of beds, total assets and age (the number of years since the hospital was founded), are introduced in logarithmic form (logBeds, $\log A s s e t s, \log A g e)$, the year, the hospital specialty, and location. The year 2010 represents a turning point in the Spanish public health system because that was the year of the first large cuts in public health spending. The year has been introduced through eight dummies variables that take the value 1 for each year from 2005 to 2012 . The hospital's specialty is registered by 10 dichotomous variables for the type of pathology treated (e.g. general, surgical, and trauma).

For general and surgical hospitals, we calculated an index for the level of technological equipment (IndTec) by a principal component analysis of the numbers of the following devices: CAT scanners, MRI machines, Gamma camera, Hemodynamic Facilities, Angiology by Digital Subtraction, linear accelerators, PET scanners, CATPET scanners, mammogram machines, and bone-density scanners. For surgical hospitals, we only included in binary form (has or does not have) the different types of apparatus, excluding those that are very unusual in Spanish surgical hospitals (PET, CAT-PET and linear accelerators). The first main component of each of the analyses has been standardised so that the average hospital has a score of zero. For hospitals that 
are neither general nor surgical, the technical index takes a score of zero, that is, without intra-group variability, so that the model does not consider technology for these specialised institutions such as psychiatric or geriatric hospitals in which advanced diagnostic technology is not used.

The location was registered by dichotomous variables for Spain's autonomous regions $(\boldsymbol{A A R R})$. An added dummy variable (Capital) takes the value 1 if the hospital is located in the provincial capital and zero otherwise. Finally, for the robustness analysis (probit), population size and per capita income of the autonomous region were also included.

Table A1 in the appendix lists the variables, showing how they were calculated and referring to previous studies in which they were used.

\subsection{Econometric models}

We have estimated regression models for panel data with random effects for hospitals. The models include an autoregressive component in the time variant noise:

$$
y_{i t}=\alpha+Z_{i t} \delta+X_{i t} \beta+\eta_{i}+\varepsilon_{i t}
$$

where the dependent variable $y_{i t}$ is alternatively the ROA, ROA_EBITDA, Revenues, Cost efficiency or Op_Margin (previously defined). $\mathrm{Z}$ includes the dummy variables for the ownership types, $\mathrm{X}$ includes the covariates used as controls, $\varepsilon_{i t}$ are the random errors i.i.d. Normal with mean 0 and variance $\sigma_{\varepsilon}^{2}$, and $\eta_{i}$ are the unobserved hospital effects that are assumed to be realisations of an i.i.d. process with mean 0 and variance $\sigma_{\eta}^{2}$, independent of both the $\varepsilon_{i t}$ and the covariates $X_{i t}$ and $Z_{i t}$. The models have been estimated with the Baltagi and $\mathrm{Wu}$ (1999) Feasible Generalised Least Squares (FGLS) estimate for unbalanced panels, with $\mathrm{AR}(1)$ disturbance. The $\mathrm{AR}(1)$ structure has been tested with the locally best invariant (LBI) test by Bhargava, Franzini, and Narendranathan (1982). The LBI test modifies the Durbin-Watson test of null correlation. We used the critical values published originally in Bhargava et al. (1982). ${ }^{12}$ Stata 12 software was used for the estimation. Lastly, it should be noted that the Hausman test indicates that the null hypothesis is accepted according to which the model with random effects provides a more robust solution than the fixed-effect model $(p=0.34)$.

Additionally, we estimated them for specific subsamples: only general and surgical hospitals, because they are subject to tighter technological and institutional restrictions (Jeurissen, 2010); only hospitals with a dominant shareholder; and only hospitals with more than 50 beds.

A concern with respect to the model specification is about the assumed exogeneity of the insurance companies, that is, insurance companies could have self-selected into hospitals that have different return characteristics. To check possible endogeneity of the insurance firm decision about being dominant shareholder of a given hospital, we made an analysis in two stages. In the first stage, we estimated a probit model for each year to predict the probability that an insurance company is the dominant shareholder in the hospital. The explanatory variables are the same as in the model of financial performance, although introduced with a one-year time delay. In addition, we included two macroeconomic explanatory variables for the region, population and per capita income, 
also lagged, which can affect the decision to acquire ownership of the hospital because they influence the turnover. In the second stage, the equation of interest - explaining financial performance - is estimated, replacing the dummy variable for insurance company with the probability estimated in the first stage that the hospital had an insurance company as dominant shareholder. The goodness of fit of the probit models was assessed by the sensitivity (\% of correct predictions in the insurance group of hospitals) and the specificity (\% of correct predictions in the non-insurance group of hospitals). The sample frequency was used as the cut-point. Finally, to corroborate the temporal stability of the results, we re-estimated the models for the cross-section samples corresponding to each year of the period.

\section{Results}

\subsection{Descriptive analysis}

Although there were 179 hospitals in the final sample, the number of hospitals per year in Table 1 is between 98 and 149, depending upon the information available for each hospital and the fact that some hospitals closed and others opened in this period. Table 1 also shows the size of the population and the sample percentage for each year, the latter ranging from $30.5 \%$ of all Spanish hospitals in 2007 to $48.4 \%$ in 2011 . The last row shows the number of hospitals in each category that are part of the total sample. Thus, we see that $82 \%$ of the observations refer to hospitals with a controlling shareholder, which means that the remaining $18 \%$ did not have a controlling shareholder or that a control group was not evident from the SABI. Over the period under study, we see that among the hospitals with a controlling shareholder, the latter is more likely to be a non-financial enterprise, followed at some distance by individuals or families, insurance companies, or financial institutions, in that order.

Table 1 also shows the evolution of private for-profit hospital ownership in Spain over the period from 2005 to 2012, with the percentage of those with controlling owners increasing from $77 \%$ in 2005 to $85 \%$ in 2012. Of these controlling owners, over the entire period, approximately $35 \%$ are non-financial enterprises, $20 \%$ are individuals and families, $17 \%$ are insurance companies and $10 \%$ are banks. A decline in the presence of

Table 1. Evolution in ownership of private for-profit hospitals in Spain and sample percentages.

\begin{tabular}{lcccccccc}
\hline Year & $\begin{array}{c}\text { No hospitals } \\
\text { sample }\end{array}$ & $\begin{array}{c}\text { No hospitals } \\
\text { population }\end{array}$ & $\begin{array}{c}\text { Sample } \\
\text { percentage }\end{array}$ & $\begin{array}{c}\text { With controlling } \\
\text { shareholder }\end{array}$ & Insurers & Banks & Enterprises & $\begin{array}{c}\text { Families or } \\
\text { Individuals }\end{array}$ \\
\hline $\mathbf{2 0 0 5}$ & 98 & 312 & 31.4 & 77.55 & 24.49 & 13.27 & 32.65 & 7.14 \\
$\mathbf{2 0 0 6}$ & 110 & 316 & 34.8 & 76.36 & 19.09 & 12.73 & 34.55 & 10.91 \\
$\mathbf{2 0 0 7}$ & 98 & 321 & 30.5 & 79.59 & 21.43 & 15.31 & 30.61 & 12.24 \\
$\mathbf{2 0 0 8}$ & 137 & 323 & 42.4 & 81.02 & 14.60 & 10.22 & 33.58 & 22.63 \\
$\mathbf{2 0 0 9}$ & 143 & 331 & 43.2 & 81.12 & 14.69 & 9.79 & 32.17 & 24.48 \\
$\mathbf{2 0 1 0}$ & 146 & 324 & 45.1 & 82.88 & 15.07 & 7.53 & 36.99 & 23.29 \\
$\mathbf{2 0 1 1}$ & 149 & 308 & 48.4 & 87.25 & 14.77 & 8.05 & 38.93 & 25.50 \\
$\mathbf{2 0 1 2}$ & 128 & 305 & 42.0 & 85.16 & 15.63 & 6.25 & 39.06 & 24.22 \\
Obs. & $\mathbf{1 0 0 9}$ & $\mathbf{2 5 4 0}$ & & $\mathbf{8 2 5}$ & $\mathbf{1 7 1}$ & $\mathbf{1 0 1}$ & $\mathbf{3 5 3}$ & $\mathbf{2 0 0}$ \\
& & & & $\mathbf{( 8 2 \% )}$ & $\mathbf{( 1 7 \% )}$ & $\mathbf{( 1 0 \% )}$ & $\mathbf{( 3 5 \% )}$ & $\mathbf{( 2 0 \% )}$ \\
\hline
\end{tabular}

Variables: Insurers: Dummy $=1$ if the controlling shareholder is an insurance company; With controlling shareholder: Dummy $=1$ if a shareholder has more than $50 \%$ of the ownership; Banks, Enterprises, Families or Individuals: Dummy $=1$ if the controlling shareholder is a financial enterprise (bank, pension fund, ....), a non-financial enterprise or a family, respectively. 
insurance companies and banks is more pronounced after 2008. In contrast, there is a significant increase in the presence of individuals and families as controlling shareholders, reaching approximately 24\% between 2008 and 2012.

There are 28 hospitals controlled by an insurance company in the estimation sample. One-half of them have data for the whole period 2005-2012, and only five hospitals have data for fewer than 4 years. Conversely, only six hospitals in the final sample changed from or to insurance control. Thus, ownership stability is a common characteristic of the unlisted firms because the lack of a market complicates the transfer of large blocks of shares (Andres, 2008).

Among insurance companies listed in the final sample as hospital's dominant shareholders, the most represented is ASISA, with 58\% of the observations (hospital-years). Appearing with smaller presence are other important entities such as ADESLAS, SANITAS and DKV. Note that when identifying the dominant shareholder, some hospitals belong to groups linked to the health sector, although these organisations are companies or financial groups rather than insurance companies. Moreover, hospitals are in some cases not listed as separate entities but integrated into a group; therefore, specific financial information from them cannot be provided. ${ }^{13}$ In other cases, we found that the hospital belongs to a financial institution, which in turn is the controlling shareholder of a company health insurer. Therefore, although the hospital is linked to the insurance company, the latter is not the dominant shareholder in the hospital. ${ }^{14}$

In short, there was an increase in the presence of controlling shareholders in private forprofit hospitals, which reflects a greater concentration in ownership, with a tendency for banks to transfer control to businesses. Overall, there was a substantial degree of stability among the different types of controlling shareholders of hospitals in this period.

Table 2 presents the descriptive statistics related to return on assets and operating margins for each type of ownership. Largely, one sees a slightly higher profitability in the hospitals without a controlling shareholder. There are important differences among the types of shareholders. On average, the least profitable hospitals and those with the lowest operating margins are those whose controlling shareholders are insurance companies. A $\mathrm{t}$-test indicates that the average differences between the ROA and the operating margins of the hospitals controlled by an insurance company and the rest are significant at $1 \%$.

Table 3 shows that approximately one-half of Spain's private hospitals in the sample have some type of accord with the NHS. The sample hospitals are on average 27 years old, with an average of 100 beds, and have average assets of approximately 20 million Euros. ${ }^{15}$ By design, the technological index averages approximately zero, and the variance is small because those hospitals neither general nor surgical were given a score of zero. Approximately two-thirds of the hospitals were located in provincial capitals, and $42 \%$ of the observations corresponds to the years 2010-2012. Finally, the great majority (71.66\%) are general hospitals, with surgical (9.61\%) and geriatric (5.95\%) hospitals representing a small minority. The regions with the greatest number of hospitals in the sample were Andalusia and Catalonia, followed by Valencia, Madrid and Galicia. These five regions composed 65\% of the sample (see Table A2 in the appendix). Conversely, the tests reported in Table 3 reveal that there are significant differences between the characteristics of the hospitals whose controlling shareholder is an insurance company and those of the others. Specifically, those controlled by an insurance company are lower leveraged, larger, older, have less technological equipment, and have a lower prevalence of accords with the NHS and the Catalan public health system. 
Table 2. Ownership and financial performance of Spanish hospitals. Data pull 2005-2012.

\begin{tabular}{|c|c|c|c|c|c|c|c|c|c|c|}
\hline & \multicolumn{5}{|c|}{ ROA (\%) } & \multicolumn{5}{|c|}{ Operating Margin (\%) } \\
\hline & Aver. & Median & S. D. & Min & $\operatorname{Max}$ & Aver. & Median & S. D. & Min & $\operatorname{Max}$ \\
\hline All & 3.95 & 4.19 & 14.53 & -108.18 & 73.70 & 8.66 & 8.44 & 14.81 & -81.28 & 95.85 \\
\hline No controlling Shareholder & 4.26 & 4.20 & 10.72 & -108.18 & 21.87 & 11.02 & 10.02 & 15.36 & -81.28 & 85.42 \\
\hline With controlling shareholder & 3.89 & 4.18 & 15.26 & -82.77 & 73.70 & 8.14 & 7.97 & 14.66 & -77.75 & 95.85 \\
\hline Insurers & -2.71 & 0.68 & 14.91 & -74.81 & 26.97 & 2.28 & 4.79 & 10.76 & -75.61 & 20.47 \\
\hline Non Insurers & 5.61 & 5.44 & 14.88 & -82.77 & 73.70 & 9.96 & 9.46 & 15.20 & -81.28 & 95.85 \\
\hline Banks & 9.85 & 7.31 & 14.66 & -29.97 & 53.39 & 10.95 & 9.99 & 9.72 & -23.25 & 40.78 \\
\hline Enterprises & 4.58 & 5.32 & 15.85 & -82.77 & 73.70 & 10.42 & 10.29 & 18.26 & -69.88 & 95.84 \\
\hline Families & 5.27 & 4.88 & 12.71 & 75.11 & 64.63 & 7.67 & 7.52 & 10.46 & -77.75 & 39.18 \\
\hline t-test insurers vs non & $6.51^{* * *}$ & & & & & $6.29 * * *$ & & & & \\
\hline
\end{tabular}
insurers

Variables: No controlling shareholder: Dummy $=1$ if no shareholder has more than $50 \%$ of the ownership; With controlling shareholder: Dummy $=1$ if a shareholder has more than $50 \%$ of the ownership; Insurers: Dummy $=1$ if the controlling shareholder is an insurance company. Banks, Enterprises, Families or Individuals: Dummy $=1$ if the controlling shareholder is a financial enterprise (bank, pension fund, ....), a non-financial enterprise or a family, respectively.

${ }^{*}, * * * * *$ : significant to $10 \%, 5 \%$ and $1 \%$, respectively.

Table 3. Descriptions of control variables (average).

\begin{tabular}{|c|c|c|c|c|c|}
\hline & All & $\begin{array}{l}\text { With controlling } \\
\text { shareholder }\end{array}$ & $\begin{array}{l}\text { Insurers } \\
\text { As control } \\
\text { share }\end{array}$ & $\begin{array}{l}\text { Non } \\
\text { Insurers }\end{array}$ & $\begin{array}{c}\text { Tests for average difference insurers } \\
\text { vs non insurers }{ }^{\mathrm{a}}\end{array}$ \\
\hline Con-SS & 44.89 & 42.66 & 35.08 & 45.92 & $2.5819^{* * *}$ \\
\hline Con_Cataluña & 3.22 & 3.51 & 0 & 4.43 & $7.8588^{* * *}$ \\
\hline Concession & 1.21 & 1.45 & 1.75 & 1.37 & 0.1353 \\
\hline Leverage & 61.91 & 62.89 & 47.98 & 64.75 & $6.3234^{* * *}$ \\
\hline GrowthOp & 0.21 & 0.21 & 0.23 & 0.20 & -0.3407 \\
\hline Log beds & 1.85 & 1.83 & 1.73 & 1.86 & $3.6781^{* * *}$ \\
\hline Log assets & 9.03 & 9.02 & 8.89 & 9.02 & 1.2873 \\
\hline Age (years) & 26.89 & 26.08 & 31.21 & 24.74 & $-4.2268^{* * *}$ \\
\hline Index of Technol. & 0.01 & -0.008 & -0.20 & 0.04 & $3.6788^{* * *}$ \\
\hline Capital & 67.40 & 68.12 & 77.77 & 65.59 & $9.2626^{* * *}$ \\
\hline
\end{tabular}

Variables: With controlling shareholder: Dummy $=1$ if a shareholder has more than $50 \%$ of the ownership; Insurers: Dummy $=1$ if the controlling shareholder is an insurance company; Con-SS: Dummy $=1$ if the hospital has an accord with the Spanish public health system; Con-Cat: Dummy = 1 if the hospital has an accord with the Catalan public health system; Concession: Dummy $=1$ if the hospital is managed through an administrative concession; Leverage: (Total debt/Total assets)x100; GrowthOp: (Intangible assets/Total assets)x100; LogBeds: logarithm number of beds; LogAssets: logarithm assets; LogAge: logarithm number of years since founded; IndTec: Quantitative standardised index of technological equipment made with an analysis of principal components; Capital: Dummy = 1 if hospital is located in provincial capital.

${ }^{*}, * *{ }^{* * *}$ : significant to $10 \%, 5 \%$ and $1 \%$, respectively.

Appendix Table A3 contains the correlation matrix for the continuous variables used in the econometric analysis. Correlations among almost all of the variables are less than 0.5. Likewise, the VIF (variance inflation factor, not reported) are all lower than 2.25, with a mean of 1.47 , indicating that multicollinearity is not a problem.

\subsection{Model results}

The results estimation of the panel model data for $\mathrm{H} 1$ are presented in Table 4; models 1 and 2 explain ROA, and model 3 explains ROA_EBITDA. In all models except model 2, Insurers is the main explanatory variable, which takes the value 1 if the hospital has an 
Table 4. Ownership and performance of private hospitals in Spain 2005-2012. Estimation: panel regression data.

\begin{tabular}{|c|c|c|c|c|c|c|}
\hline \multirow{3}{*}{$\begin{array}{l}\text { Models } \\
\text { Dependent variable }\end{array}$} & \multicolumn{2}{|l|}{ (1) } & \multicolumn{2}{|c|}{$(2)$} & \multicolumn{2}{|l|}{ (3) } \\
\hline & \multicolumn{2}{|c|}{ ROA (\%) } & \multicolumn{2}{|c|}{ ROA (\%) } & \multicolumn{2}{|c|}{ ROA_EBITDA (\%) } \\
\hline & $\beta$ & S.E. & $\beta$ & S.E. & $\beta$ & S.E. \\
\hline Insurers & $-9.5792^{* * *}$ & 1.9894 & \multicolumn{2}{|c|}{ Reference } & $-8.9533^{* * *}$ & 1.9938 \\
\hline NoContSh & $-3.4476^{* *}$ & 1.4966 & $4.6843^{* *}$ & 2.1683 & $-3.4758^{* *}$ & 1.4912 \\
\hline Banks & \multicolumn{2}{|l|}{-} & $8.6813^{* * *}$ & 2.6479 & \multicolumn{2}{|l|}{-} \\
\hline Enterprises & \multicolumn{2}{|l|}{ - } & $8.9022^{* * *}$ & 2.0130 & \multicolumn{2}{|l|}{ - } \\
\hline Families & \multicolumn{2}{|l|}{-} & $8.8736^{* * *}$ & 2.3115 & \multicolumn{2}{|l|}{-} \\
\hline Con-SS & $4.5746^{* * *}$ & 1.5638 & $4.6843^{* * *}$ & 1.5628 & $4.6219^{* * *}$ & 1.5607 \\
\hline Con-Cat & -2.0329 & 4.0709 & -2.0459 & 4.0958 & -1.8501 & 4.0829 \\
\hline Concession & 9.9737 & 6.0940 & 9.8105 & 6.0890 & $10.7730^{*}$ & 6.1272 \\
\hline Leverage & $-0.2905^{* * *}$ & 0.0171 & $-0.2898^{* * *}$ & 0.0172 & $-0.2859^{* * *}$ & 0.0170 \\
\hline GrowthOp & 0.1638 & 0.3776 & 0.1704 & 0.3786 & 0.1615 & 0.3719 \\
\hline LogAssets & 0.2144 & 0.6499 & 0.2071 & 0.6575 & -0.7708 & 0.6514 \\
\hline LogAge & -0.9445 & 1.5939 & $-0 . .9813$ & 1.6247 & -0.8260 & 1.5827 \\
\hline LogBeds & -1.7811 & 2.3593 & -1.6559 & 2.3730 & -2.3973 & 2.3740 \\
\hline IndTec & 1.2677 & 0.8159 & 1.2634 & 0.8162 & $1.9614^{* *}$ & 0.8149 \\
\hline Capital & -1.9785 & 1.7486 & -2.0702 & 1.7587 & -1.4787 & 1.7640 \\
\hline Year 2005 & \multicolumn{2}{|c|}{ Reference } & \multicolumn{2}{|c|}{ Reference } & \multicolumn{2}{|c|}{ Reference } \\
\hline Year 2006 & 0.2642 & 1.0821 & 0.1867 & 1.0865 & 0.2267 & 1.0625 \\
\hline Year 2007 & -0.2328 & 1.2804 & -0.2511 & 1.2849 & -0.2187 & 1.2598 \\
\hline Year 2008 & -0.8021 & 1.2767 & -0.7817 & 1.2833 & -1.0528 & 1.2586 \\
\hline Year 2009 & -0.3098 & 1.2955 & -0.2963 & 1.3026 & -0.4959 & 1.2781 \\
\hline Year 2010 & $-4.2186^{* * *}$ & 1.3086 & $-4.2091^{* * *}$ & 1.3171 & $-4.3710^{* * *}$ & 1.2916 \\
\hline Year 2011 & $-3.9477^{* * *}$ & 1.3313 & $-3.9413^{* * *}$ & 1.3399 & $-4.2441^{* * *}$ & 1.3147 \\
\hline Year 2012 & $-4.2013^{* * *}$ & 1.3724 & $-4.1999 * * *$ & 1.3831 & $-4.5726^{* * *}$ & 1.3552 \\
\hline Specialty & \multicolumn{2}{|c|}{ Yes $^{a}$} & \multicolumn{2}{|c|}{ Yes ${ }^{b}$} & \multicolumn{2}{|c|}{ Yes $^{b}$} \\
\hline AARR & \multicolumn{2}{|c|}{ Yes $^{a}$} & \multicolumn{2}{|c|}{ Yes $^{b}$} & \multicolumn{2}{|c|}{ Yes $^{b}$} \\
\hline Constant & $28.8675^{* * *}$ & 6.9250 & $19.7975^{* * *}$ & 7.0633 & $44.0003^{* * *}$ & 6.9367 \\
\hline No observations & \multicolumn{2}{|c|}{1009} & \multicolumn{2}{|c|}{1009} & \multicolumn{2}{|c|}{1009} \\
\hline № hospitals & \multirow{2}{*}{\multicolumn{2}{|c|}{179}} & 179 & & 179 & \\
\hline$R^{2}$ & & & & & & \\
\hline Within & 0.2853 & & 0.2857 & & 0.2799 & \\
\hline Between & 0.3669 & & 0.3637 & & 0.3518 & \\
\hline Overall & 0.3607 & & 0.3571 & & 0.3511 & \\
\hline Estimated rho & 0.4371 & & 0.4345 & & 0.4544 & \\
\hline$\%$ variance & & & & & & \\
\hline$\eta$ modified Bhargava et al. Durbin-Watson test & 1.3721 & & 1.3748 & & 1.3573 & \\
\hline
\end{tabular}

Variables: ROA: (EBIT/Total assets) x100; ROA_EBITDA: (EBITDA/Total assets) x100; Insurers: Dummy $=1$ if the controlling shareholder is an insurance company; NoContSh: Dummy $=1$ if no shareholder has more than $50 \%$ of the ownership; Banks, Enterprises, Families: Dummy $=1$ if the controlling shareholder is a financial enterprise (bank, pension fund, ....), a non-financial enterprise or a family, respectively; Con-SS: Dummy $=1$ if the hospital has an accord with the Spanish public health system; Con-Cat: Dummy $=1$ if the hospital has an accord with the Catalan public health system; Concession: Dummy $=1$ if the hospital is managed through an administrative concession; Leverage: (Total debt/Total assets)x100; GrowthOp: (Intangible assets/Total assets)x100; LogBeds: logarithm number of beds; LogAssets: logarithm assets; LogAge: logarithm number of years since founded; IndTec: Quantitative standardised index of technological equipment made with an analysis of principal components; Capital: Dummy $=1$ if hospital is located in provincial capital; Year: dummies $=1$ for each year from 2005 to 2012: Specialty: Dummies specialty (see Table A1 appendix); AARR: Dummies Autonomous Regions (see Table A2 appendix).

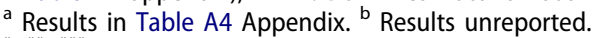

${ }^{*}{ }^{* * * * * *}$ : significant to $10 \%, 5 \%$ and $1 \%$, respectively

insurance company as the controlling shareholder. In model 2, all of the other types of controlling shareholders are included as dummy variables with insurers as the reference category. The fit of the models is fairly good, with the overall coefficient of determination between 0.35 and 0.36 . The autocorrelation coefficients of first-order estimates are significant for the Bhargava et al. (1982) test, suggesting that the estimation method is appropriate. The effect of hospital accumulates $43 \%$ of the error variance. 
Concerning the interpretation of the coefficients estimated, we note that the return on assets of hospitals without a dominant shareholder is not significantly different from returns to hospitals with a controlling shareholder. In models 1 and 3 (Table 4), the variable Insurers has a significantly negative effect, which indicates that hospitals whose controlling shareholder is an insurance company are less profitable than are those controlled by any other type of shareholder. In model 2, the variable Insurers is replaced by the three variables representing financial entities, business, and families and individuals as controlling shareholders. The three variables have a significantly positive sign, which corroborates the results of the previous model although showing possible differences between the types of owners in comparison to insurance companies (taken as the reference). The test for parametric subsets of equality of the coefficients for ownership in the hands of businesses, families, and banks does not reject H0 (chi2(2) $0.01 ; \mathrm{p}=0.99$ in model 2). Therefore, models 1 and 3, which include only a dummy for insurers, are appropriate. Hence, there is evidence that hospitals belonging to insurance companies differ in return on assets from those with other types of owners. The results of model 3 are similar in sign and significance to those of model 1 . Therefore, the results support $\mathrm{H} 1 \mathrm{a}$, revealing a predominance of the tunnelling effect in the insurance company-hospital relationship.

In terms of control variables, to have a concierto is significantly positive. In addition, one notes that the hospitals with accords with the Catalan public health system and also those hospitals that operate with management concessions are no different in terms of performance than are those with no government accords. Leverage variable presents a negative sign, which suggests that the more indebted hospitals have lower profitability. The technological index is significantly positive (only in the model 3), indicating that general and surgical hospitals that have the most advanced equipment are the most profitable. Table 4 also shows that from 2010 on, private hospitals began to be less profitable. In terms of hospital specialty (Appendix Table A4), there are few significant differences only in the psychiatric hospitals. Finally, in terms of autonomous region, the private hospitals of Andalusia (the reference region) are significantly more profitable than are those of the four other regions, while La Rioja is the only region significantly more profitable than Andalusia (see Appendix Table A4).

With the aim of checking hypotheses $\mathrm{H} 2$ and $\mathrm{H} 3$, models 4 and 5 are estimated; the dependent variables are revenues and cost efficiency, respectively. These models have good fit, with overall coefficients of determination are between 0.38 and 0.41 . The effect of hospital accumulates $73 \%$ and $75 \%$ of the error variance, respectively.

In model 4 , the variable Insurers has a significantly positive effect, which suggests that the hospitals controlled by an insurance company have a greater volume of revenues (over total assets) than do the rest of the hospitals. These results support hypothesis $\mathrm{H} 2 \mathrm{a}$, according to which an increase in the number of patients (and activity) leads to more revenues. However, the positive sign in the Insurers variable in model 5 suggests a greater volume of expenses, that is, lower-cost efficiency in the hospitals controlled by an insurance company. This result supports hypothesis $\mathrm{H} 3 \mathrm{~b}$ and shows that the increase in the expenses derived from the growth in the number of patients is greater than the possible reduction in those expenses derived from the pressure of the insurance company. Based on the arguments about vertical integration, it is possible to assert that the vertical integration strategy damages the hospital.

Concerning the control variables, it is remarkable that in models 4 and 5, the results are different from those obtained in models 1,2 , and 3 . This fact is logical because the 
Table 5. Ownership and performance of private hospitals in Spain 2005-2012. Estimation: panel regression data.

\begin{tabular}{|c|c|c|c|c|c|c|}
\hline \multirow{3}{*}{$\begin{array}{l}\text { Models } \\
\text { Dependent variable }\end{array}$} & \multicolumn{2}{|l|}{ (4) } & \multicolumn{2}{|l|}{ (5) } & \multicolumn{2}{|l|}{ (6) } \\
\hline & \multicolumn{2}{|c|}{$\operatorname{Rev}(\%)$} & \multicolumn{2}{|c|}{ Cost_Efi(\%) } & \multicolumn{2}{|c|}{ OP_Margin (\%) } \\
\hline & $\beta$ & S.E. & $\beta$ & S.E. & $\beta$ & S.E. \\
\hline Insurers & $25.0252^{* * *}$ & 9.5211 & $33.5524^{* * *}$ & 9.6844 & $-6.4578^{* * *}$ & 2.2393 \\
\hline NoContSh & $-10.8636^{*}$ & 6.2714 & -8.3082 & 6.4538 & -0.7574 & 1.6677 \\
\hline Con-SS & $11.8152^{*}$ & 6.8062 & 7.9441 & 6.9565 & $4.8909^{* * *}$ & 1.7445 \\
\hline Con-Cat & 10.2920 & 20.0842 & 11.5787 & 20.0821 & 1.5695 & 4.5618 \\
\hline Concession & $56.6714^{*}$ & 34.0534 & 46.8797 & 33.6762 & 2.2894 & 6.8750 \\
\hline Leverage & $0.1203^{*}$ & 0.0698 & $0.4633^{* * *}$ & 0.0719 & $-0.1575^{* * *}$ & 0.0190 \\
\hline GrowthOp & -0.8737 & 1.2984 & -0.8123 & 1.3721 & -0.3912 & 0.4169 \\
\hline LogAssets & $-58.4591^{* * *}$ & 3.1329 & $-57.9182^{* * *}$ & 3.1719 & $1.6671^{* *}$ & 0.7306 \\
\hline LogAge & 9.2849 & 6.1671 & $13.5038^{* *}$ & 6.5247 & -0.3912 & 1.7856 \\
\hline LogBeds & $66.2626^{* * *}$ & 12.7021 & $66.4745^{* * *}$ & 12.7069 & 1.6671 & 2.6714 \\
\hline IndTec & 5.0259 & 3.6199 & 4.1136 & 3.7033 & -0.3960 & 0.9123 \\
\hline Capital & $19.0509^{* *}$ & 10.3177 & $20.3188^{* *}$ & 10.1773 & $-0.9217^{* *}$ & 1.9869 \\
\hline Year 2005 & \multicolumn{2}{|c|}{ Reference } & \multicolumn{2}{|c|}{ Reference } & \multicolumn{2}{|c|}{ Reference } \\
\hline Year 2006 & $7.0662^{* *}$ & 3.5299 & $6.7940^{*}$ & 3.7794 & 0.3349 & 1.1993 \\
\hline Year 2007 & $14.2116^{* * *}$ & 4.3674 & $14.3060^{* * *}$ & 4.5892 & -1.0655 & 1.4083 \\
\hline Year 2008 & $13.9816^{* * *}$ & 4.5519 & $14.4351^{* * *}$ & 4.6966 & -1.3877 & 1.3969 \\
\hline Year 2009 & $12.6252^{* * *}$ & 4.7073 & $12.4790^{* * *}$ & 4.8231 & -0.8778 & 1.4157 \\
\hline Year 2010 & $9.8487^{* *}$ & 4.8107 & $13.4142^{* * *}$ & 4.9095 & $-3.4074^{* *}$ & 1.4296 \\
\hline Year 2011 & $11.4090^{* *}$ & 4.9482 & $14.4183^{* * *}$ & 5.0387 & $-3.9889^{* * *}$ & 1.4549 \\
\hline Year 2012 & 5.6869 & 5.0955 & $8.9897^{*}$ & 5.1893 & $-3.8984^{* * *}$ & 1.5000 \\
\hline Specialty & \multicolumn{2}{|c|}{ Yes $^{a}$} & \multicolumn{2}{|c|}{ Yes $^{a}$} & \multicolumn{2}{|c|}{ Yes ${ }^{b}$} \\
\hline AARR & \multicolumn{2}{|c|}{ Yes $^{\mathrm{a}}$} & \multicolumn{2}{|c|}{ Yes $^{\mathrm{a}}$} & \multicolumn{2}{|c|}{ Yes $^{b}$} \\
\hline Constant & $483.4555^{* * *}$ & 34.0279 & $445.8013^{* * *}$ & 34.3016 & 12.2010 & 7.7825 \\
\hline No observations & \multicolumn{2}{|c|}{1009} & \multicolumn{2}{|c|}{1009} & \multicolumn{2}{|c|}{1009} \\
\hline № hospitals & \multicolumn{2}{|c|}{179} & \multirow{2}{*}{\multicolumn{2}{|c|}{179}} & \multicolumn{2}{|c|}{179} \\
\hline \multicolumn{5}{|l|}{$\mathrm{R}^{2}$} & & \\
\hline Within & 0.3316 & & 0.3214 & & 0.1128 & \\
\hline Between & 0.4064 & & 0.4486 & & 0.2934 & \\
\hline Overall & 0.3803 & & 0.4145 & & 0.2299 & \\
\hline Estimated rho & 0.7552 & & 0.7325 & & 0.4688 & \\
\hline \multicolumn{7}{|l|}{$\%$ variance } \\
\hline$\eta$ modified Bhargava et al. Durbin-Watson test & 1.0959 & & 1.2284 & & 1.4179 & \\
\hline
\end{tabular}

Variables: Revenues: (Revenues/Total assets) x100; Cost efficiency: (Operating cost/total assets) x100; OP_Margin: EBITDA/Operating revenues) $\times 100$; Insurers: Dummy $=1$ if the controlling shareholder is an insurance company; NoContSh: Dummy $=1$ if no shareholder has more than $50 \%$ of the ownership; Con-SS: Dummy $=1$ if the hospital has an accord with the Spanish public health system; Con-Cat: Dummy $=1$ if the hospital has an accord with the Catalan public health system; Concession: Dummy $=1$ if the hospital is managed through an administrative concession; Leverage: Total debt/Total assets; GrowthOp: Intangible assets/Total assets; LogBeds: logarithm number of beds; LogAssets: logarithm assets; LogAge: logarithm number of years since founded; IndTec: Quantitative standardised index of technological equipment made with an analysis of principal components; Capital: Dummy = 1 if hospital is located in provincial capital; Year: dummies = 1 for each year from 2005 to 2012; Specialty: Dummies specialty (see Table A1 appendix); AARR: Dummies Autonomous Regions (see Table A2 appendix).

${ }^{a}$ Results unreported. ${ }^{\mathrm{b}}$ Results in Table A4 Appendix.

${ }^{*}{ }^{* * *}{ }^{* * *}$ : significant to $10 \%, 5 \%$ and $1 \%$, respectively

dependent variables are the revenues and the expenses, whereas in the previous models, they are the results. The number of beds and age are positive, and the total asset has a negative effect. The leverage is positive in the models 4 and 5. Finally, the hospitals located in provincial capitals have greater revenues and expenses. In addition, to have a concierto is significantly positive in the revenues model, but it is not significant in the expense model. Hospital size, proxied by the logarithm of assets, is significantly positive.

Finally, according to $\mathrm{H} 4$, with the aim of analysing the joint effect of revenues and expenses in hospital performance, model 6, whose dependent variable is the operating margin, is estimated. As seen in Table 5, the Insurers variable is 
significantly negative, which demonstrates that the increase in the expenses is not compensated for by the increase in the revenues. Consequently, the operating margin in the hospitals controlled by the insurance companies is reduced, compared with the rest of the hospitals. The results on the control variables are similar to those obtained in models 1,2 and 3.

\subsubsection{Robustness analysis}

To test the robustness of the models, models 1 and 6 have been re-estimated for different variables and econometric methods. The results are presented in the models 7 to 9 for ROA (Table 6) and models 10 to 12 for Operating Margin (Table 7). First, in the model 7 , the sales variations have been considerate in order to approximate the growth opportunities. The results are similar to the model $1 .{ }^{16}$ Second, with the aim of controlling the presence of outliers, the methodology developed by Hadi (1992, 1994)) has been applied, and the extreme observations in the dependent variables have been eliminated. ${ }^{17}$ The results of are presented in model 8 . As it can be observed, the results are not sensitive to outlier treatment, except in the concierto variable, which loses statistical significance in these models, although it maintains the positive sign. Thirdly, concerning the possible self-selection bias by insurance companies, we made an analysis in two stages. In the first stage, we estimated probit models, with the insurer variable as a dependent and considering the same explanatory variables as in the previous models (with a lagged), and we have added the GDP per capita and the population in each autonomous community as exogenous variables. The results (unreported ${ }^{18}$ ) have good fit, with global sensitivity of $85 \%$ (percentage of correct predictions for the hospitals controlled by insurance companies) and globally specify $79 \%$ (percentage of correct predictions for the hospitals controlled by other types of shareholders). Model 9 in Table 6 reports the estimation results of the model, explaining the ROA (second stage in the method described above). The number of observations in this model is reduced to 535 because the probit model was estimated using lagged variables. The results about Insurers variable maintain the negative sign and the statistic signification. The results of models 10 to 12 (Table 7) are similar to those obtained in the model 6 (dependent variable Operating Margin), except in Con.SS variable in the models 11 and 12 . Additionally, Age variable is significant and negative in all the models and Capital variable is only significant in the model 10.

As an additional analysis, the model 1 has been re-estimated for several subsamples. The estimated results are reported in Table 8 (models 13 to 15). Model 13 is estimated excluding the hospitals without a dominant shareholder $(\mathrm{n}=152$ hospitals, 825 observations). Model 14 includes the subsample of only general and surgical hospitals ( $\mathrm{n}=142$ hospitals, 820 observations), and model 15 works with the subsample of hospitals with more than 50 beds ( $n=122$ hospitals, 701 observations). In the three models, the results are similar to those discussed for model 1.

Finally, the model 1 has been estimated year by year using OLS, and the main conclusions hold. The results of the estimation corroborate those initially obtained (see Table A5 Appendix). 
Table 6. Ownership and performance of private hospitals in Spain 2005-2012. Robustness analysis (I). Estimation: panel regression data. Dependent variable: ROA (\%).

\begin{tabular}{|c|c|c|c|c|c|c|}
\hline \multirow[b]{2}{*}{ Models } & \multicolumn{2}{|l|}{$(7)^{a}$} & \multicolumn{2}{|c|}{$(8)^{b}$} & \multicolumn{2}{|c|}{$(9)^{c}$} \\
\hline & $\beta$ & S.E. & $\beta$ & S.E. & $\beta$ & S.E. \\
\hline Insurers & $-10.1936^{* * *}$ & 2.2170 & $-7.9082^{* * *}$ & 1.4297 & \multicolumn{2}{|l|}{-} \\
\hline Insurers_p & \multicolumn{2}{|l|}{-} & \multicolumn{2}{|l|}{-} & $-4.3838^{* *}$ & 2.1632 \\
\hline NoContSh & $-4.4286^{* * *}$ & 1.6844 & $-2.5921^{* *}$ & 1.0763 & -0.1608 & 1.5389 \\
\hline Con-SS & $6.0498^{* * *}$ & 1.7163 & 1.2865 & 1.1541 & 1.0118 & 1.6175 \\
\hline Con-Cat & -1.0018 & 4.3441 & -3.4150 & 2.8862 & -1.1924 & 7.2618 \\
\hline Concession & $13.2344^{* *}$ & 6.7742 & 1.4550 & 4.3952 & -1.7063 & 6.2192 \\
\hline Leverage & $-0.2651^{* * *}$ & 0.0191 & $-0.1444^{* * *}$ & 0.0143 & $-0.0344^{*}$ & 0.0204 \\
\hline GrowthOp & -0.2391 & 0.2652 & 0.0749 & 0.2704 & 0.1431 & 0.6477 \\
\hline LogAssets & 0.9238 & 0.7292 & 0.0581 & 0.5000 & 0.0228 & 0.6677 \\
\hline LogAge & 0.5119 & 1.9178 & $-2.5165^{* *}$ & 1.1793 & $-4.0643^{* *}$ & 1.8563 \\
\hline LogBeds & -2.9896 & 2.6647 & 0.2558 & 1.7004 & 1.3049 & 2.2719 \\
\hline IndTec & 1.0634 & 0.8991 & 0.9373 & 0.5837 & $1.2804^{*}$ & 0.7469 \\
\hline Capital & $-3.4187^{*}$ & 1.9345 & -0.4940 & 1.2872 & 0.4684 & 1.7551 \\
\hline Year $2005^{d}$ & \multicolumn{2}{|l|}{-} & \multicolumn{2}{|c|}{ Reference } & \multicolumn{2}{|l|}{-} \\
\hline Year 2006 & $5.2046^{* * *}$ & 1.3426 & -0.8144 & 0.7827 & 2.0660 & 1.4169 \\
\hline Year 2007 & $4.2663^{* * *}$ & 1.2987 & -0.6293 & 0.9336 & 2.1673 & 1.3330 \\
\hline Year 2008 & $3.2635^{* * *}$ & 1.2609 & -0.7273 & 0.9445 & $2.5216^{* *}$ & 1.3180 \\
\hline Year 2009 & $4.2635^{* * *}$ & 1.1294 & -0.5727 & 0.9538 & $2.4325^{* *}$ & 1.1002 \\
\hline Year 2010 & 0.1577 & 1.0752 & $-2.7141^{* * *}$ & 0.9675 & 0.1526 & 1.0315 \\
\hline Year 2011 & 0.1722 & 0.9328 & $-2.3224^{* *}$ & 0.9859 & 0.4928 & 0.8767 \\
\hline Year 2012 & \multicolumn{2}{|c|}{ Reference } & $-3.2426^{* * *}$ & 1.0191 & \multicolumn{2}{|c|}{ Reference } \\
\hline Specialty ${ }^{\mathrm{e}}$ & \multicolumn{2}{|c|}{ Yes } & \multicolumn{2}{|l|}{ Yes } & \multicolumn{2}{|c|}{ Yes } \\
\hline AARR ${ }^{\mathrm{e}}$ & \multicolumn{2}{|l|}{ Yes } & \multicolumn{2}{|l|}{ Yes } & \multicolumn{2}{|c|}{ Yes } \\
\hline Constant & $17.7183^{* *}$ & 8.0758 & $21.5425^{* * *}$ & 5.2100 & 11.4836 & 7.1894 \\
\hline No observations & \multicolumn{2}{|l|}{808} & \multicolumn{2}{|c|}{929} & \multicolumn{2}{|c|}{535} \\
\hline No hospitals & \multirow{2}{*}{\multicolumn{2}{|c|}{177}} & \multicolumn{2}{|c|}{174} & \multicolumn{2}{|c|}{138} \\
\hline$R^{2}$ & & & & & & \\
\hline Within & \multicolumn{2}{|l|}{0.2679} & \multicolumn{2}{|l|}{0.1293} & \multicolumn{2}{|l|}{0.0379} \\
\hline Between & \multicolumn{2}{|l|}{0.4030} & 0.3959 & & 0.3367 & \\
\hline Overall & 0.3701 & & 0.2923 & & 0.2326 & \\
\hline Estimated rho & 0.5149 & & 0.4415 & & 0.4565 & \\
\hline$\%$ variance & & & & & & \\
\hline$\eta$ modified Bhargava et al. Durbin-Watson test & 1.4045 & & 1.2817 & & 1.2843 & \\
\hline
\end{tabular}

Variables: ROA: (EBIT/Total assets) $\times 100$; Insurers: Dummy $=1$ if the controlling shareholder is an insurance company; Insurers_p: estimated probability (probit models) that an insurance company is the dominant shareholder; NoContSh: Dummy = 1 if no shareholder has more than $50 \%$ of the ownership; Con-SS: Dummy $=1$ if the hospital has an accord with the Spanish public health system; Con-Cat: Dummy $=1$ if the hospital has an accord with the Catalan public health system; Concession: Dummy $=1$ if the hospital is managed through an administrative concession; Leverage: Total debt/Total assets; GrowthOp: Intangible assets/Total assets; LogBeds: logarithm number of beds; LogAssets: logarithm assets; LogAge: logarithm number of years since founded; IndTec: Quantitative standardised index of technological equipment made with an analysis of principal components; Capital: Dummy = 1 if hospital is located in provincial capital; Year: dummies $=1$ for each year from 2005 to 2012; Specialty: Dummies specialty (see Table A1 appendix); AARR: Dummies Autonomous Regions (see Table A2 appendix).

a The growth opportunities are proxy by the revenues variation $=\left(\right.$ revenues $_{\mathrm{t}}$-revenues $\left._{\mathrm{t}-1}\right) /$ revenues $_{\mathrm{t}-1}$

${ }^{\mathrm{b}}$ The sample are depurated by outliers according Hadi $\left.(1992,1994)\right)$ methodology.

c Results of second stage, the result of first stage (probit model) are unreported.

d In Models 7 and 9, the year 2005 is eliminated because some variables are lagged. The reference year is 2012.

e Results unreported.

${ }^{*}, * * * * *$ : significant to $10 \%, 5 \%$ and $1 \%$, respectively

\section{Discussion, conclusion, implications}

This study is the first to explore in depth how profitability of for-profit private hospitals relates to the types of shareholders who control them. It has detected underlying phenomena and provided objective information addressing the very ideological ongoing debate about the privatisation of specialised assistance throughout Europe. 
Table 7. Ownership and performance of private hospitals in Spain 2005-2012. Robustness analysis (II). Estimation: panel regression data. Dependent variable: OP_Margin (\%).

\begin{tabular}{|c|c|c|c|c|c|c|}
\hline \multirow[b]{2}{*}{ Models } & \multicolumn{2}{|c|}{$(10)^{a}$} & \multicolumn{2}{|c|}{$(11)^{b}$} & \multicolumn{2}{|c|}{$(12)^{c}$} \\
\hline & $\beta$ & S.E. & $\beta$ & S.E. & $\beta$ & S.E. \\
\hline Insurers & $-4.1911^{*}$ & 2.3794 & $-7.3903^{* * *}$ & 1.4471 & \multicolumn{2}{|l|}{-} \\
\hline Insurers_p & \multicolumn{2}{|l|}{-} & \multicolumn{2}{|l|}{-} & $-5.5361^{* *}$ & 2.4562 \\
\hline NoContSh & 0.5217 & 1.6741 & $-2.5994^{* *}$ & 1.0865 & -0.3159 & 1.5623 \\
\hline Con-SS & $5.3774^{* * *}$ & 1.7348 & 1.4685 & 1.1671 & 0.7615 & 1.6471 \\
\hline Con-Cat & 0.1357 & 4.7367 & -3.1286 & 2.9204 & -1.3238 & 7.2234 \\
\hline Concession & -2.5961 & 7.7879 & 2.7485 & 4.4532 & -1.2144 & 6.3504 \\
\hline Leverage & $-0.1567^{* * *}$ & 0.0189 & $-0.1433^{* * *}$ & 0.0145 & $-0.0349 *$ & 0.0205 \\
\hline GrowthOp & $-0.4421^{*}$ & 0.2289 & 0.0387 & 0.2719 & 0.1498 & 0.6478 \\
\hline LogAssets & $2.5158^{* * *}$ & 0.7955 & $-1.0212^{* *}$ & 0.5062 & 0.0160 & 0.6796 \\
\hline LogAge & $-3.7118^{* *}$ & 1.8694 & $-2.3430^{* *}$ & 1.1898 & $-3.9359^{* *}$ & 1.8778 \\
\hline LogBeds & -0.6003 & 3.0827 & -0.1682 & 1.7241 & 1.0940 & 2.3249 \\
\hline IndTec & 1.0501 & 0.9114 & 1.6382 & 0.5898 & 1.2381 & 0.7555 \\
\hline Capital & $-6.9356^{* * *}$ & 2.3076 & 1.6381 & 1.3064 & 0.7280 & 1.8081 \\
\hline Year $2005^{d}$ & \multicolumn{2}{|l|}{-} & \multicolumn{2}{|c|}{ Reference } & \multicolumn{2}{|l|}{-} \\
\hline Year 2006 & $3.6364 * * *$ & 1.2545 & -0.8005 & 0.7865 & 2.2030 & 1.4095 \\
\hline Year 2007 & $3.1236^{* * *}$ & 1.1954 & -0.6306 & 0.9378 & $2.2456^{*}$ & 1.3233 \\
\hline Year 2008 & $3.2363^{* * *}$ & 1.1427 & -1.004 & 0.9487 & $2.6419 * *$ & 1.3103 \\
\hline Year 2009 & $3.5130^{* * *}$ & 1.0161 & -0.7882 & 0.9580 & $2.4384^{* *}$ & 1.0906 \\
\hline Year 2010 & 1.1639 & 0.9375 & $-2.9781^{* * *}$ & 0.9719 & 0.1392 & 1.0232 \\
\hline Year 2011 & 1.2235 & 0.7760 & $-2.7384^{* * *}$ & 0.9905 & 0.4884 & 0.8739 \\
\hline Year 2012 & \multicolumn{2}{|c|}{ Reference } & $-3.5917^{* * *}$ & 1.0240 & \multicolumn{2}{|c|}{ Reference } \\
\hline Specialty & \multicolumn{2}{|c|}{ Yes } & \multicolumn{2}{|l|}{ Yes } & \multicolumn{2}{|c|}{ Yes } \\
\hline AARR $^{\mathrm{e}}$ & \multicolumn{2}{|l|}{ Yes } & \multicolumn{2}{|l|}{ Yes } & \multicolumn{2}{|c|}{ Yes } \\
\hline Constant & 6.8709 & 8.8326 & $37.5700^{* * *}$ & 5.2734 & 11.8206 & 7.3307 \\
\hline No observations & \multicolumn{2}{|c|}{805} & \multicolumn{2}{|l|}{929} & \multicolumn{2}{|c|}{534} \\
\hline No hospitals & \multirow{2}{*}{\multicolumn{2}{|c|}{177}} & \multicolumn{2}{|l|}{174} & \multicolumn{2}{|c|}{138} \\
\hline \multicolumn{5}{|l|}{$\mathrm{R}^{2}$} & & \\
\hline Within & \multicolumn{2}{|l|}{0.1928} & \multicolumn{2}{|l|}{0.1366} & \multicolumn{2}{|l|}{0.0421} \\
\hline Between & 0.2555 & & 0.3799 & & 0.3303 & \\
\hline Overall & 0.2350 & & 0.2836 & & 0.2260 & \\
\hline Estimated rho & 0.6977 & & 0.404 & & 0.4855 & \\
\hline$\%$ variance & & & & & & \\
\hline$\eta$ modified Bhargava et al. Durbin-Watson test & 1.1485 & & 1.2961 & & 1.2886 & \\
\hline
\end{tabular}

Variables: OP_Margin: EBITDA/Operating revenues)x100; Insurers: Dummy = 1 if the controlling shareholder is an insurance company; Insurers_p: estimated probability (probit models) that an insurance company is the dominant shareholder; NoContSh: Dummy $=1$ if no shareholder has more than $50 \%$ of the ownership; Con-SS: Dummy $=1$ if the hospital has an accord with the Spanish public health system; Con-Cat: Dummy $=1$ if the hospital has an accord with the Catalan public health system; Concession: Dummy $=1$ if the hospital is managed through an administrative concession; Leverage: Total debt/Total assets; GrowthOp: Intangible assets/Total assets; LogBeds: logarithm number of beds; LogAssets: logarithm assets; LogAge: logarithm number of years since founded; IndTec: Quantitative standardised index of technological equipment made with an analysis of principal components; Capital: Dummy $=1$ if hospital is located in provincial capital; Year: dummies $=1$ for each year from 2005 to 2012; Specialty: Dummies specialty (see Table A1 appendix); AARR: Dummies Autonomous Regions (see Table A2 appendix).

${ }^{\text {a }}$ The growth opportunities are proxy by the revenues variation $=\left(\right.$ revenues $_{t}$-revenues $\left._{t-1}\right) /$ revenues $_{t-1}$

${ }^{\mathrm{b}}$ The sample are depurated by outliers according Hadi $(1992,1994)$ methodology.

c Results of second stage, the result of first stage (probit model) are unreported.

d In Models 10 and 12, the year 2005 is eliminated because some variables are lagged. The reference year is 2012.

e Results unreported.

${ }^{*},{ }^{* * * * *}$ : significant to $10 \%, 5 \%$ and $1 \%$, respectively

Countries such as Sweden, Finland and the United Kingdom, in which public hospitals have traditionally provided care, are exploring forms of privatisation as alternatives.

The private hospital sector in Spain is quantitatively and qualitatively important, but relatively opaque. Hence the importance of a study like this for providing light on the subject. The years under examination, 2005 to 2012, have brought changes in the size and composition of the sector, transfers of ownership, consolidation of networks, the 
Table 8. Ownership and performance of private hospitals in Spain 2005-2012. Robustness analysis (III). Estimation: panel regression data. Dependent variable: ROA (\%).

\begin{tabular}{|c|c|c|c|c|c|c|}
\hline \multirow{3}{*}{$\frac{\text { Models }}{\text { Sample }}$} & \multicolumn{2}{|l|}{ (13) } & \multicolumn{2}{|l|}{$(14)$} & \multicolumn{2}{|c|}{ (15) } \\
\hline & \multicolumn{2}{|c|}{$\begin{array}{l}\text { Hospitals with } \\
\text { controlling } \\
\text { shareholder }\end{array}$} & \multicolumn{2}{|c|}{$\begin{array}{c}\text { General and } \\
\text { surgical hospitals }\end{array}$} & \multicolumn{2}{|c|}{$\begin{array}{l}\text { Hospitals with more } \\
\text { than } 50 \text { beds }\end{array}$} \\
\hline & $\beta$ & S.E. & $\beta$ & S.E. & $\beta$ & S.E. \\
\hline Insurers & $-10.1708^{* * *}$ & 2.1143 & $-9.7283^{* * *}$ & 2.0989 & $-9.3082^{* * *}$ & 2.3468 \\
\hline NoContSh & \multicolumn{2}{|l|}{-} & $-2.8090^{*}$ & 1.5597 & -2.452 & 1.6595 \\
\hline Con-SS & $5.6866^{* * *}$ & 1.7376 & $3.2413^{* * *}$ & 1.7095 & $3.7920^{* *}$ & 1.8420 \\
\hline Con-Cat & -0.6316 & 4.2806 & 0.7203 & 4.2586 & -2.4699 & 4.9641 \\
\hline Concession & $13.2108^{* *}$ & 6.4100 & 6.8769 & 6.3271 & 8.8777 & 6.2714 \\
\hline Leverage & $-0.2883^{* * *}$ & 0.0187 & $-0.2690^{* * *}$ & 0.0197 & $-0.2949^{* * *}$ & 0.0210 \\
\hline GrowthOp & 0.0252 & 0.4039 & 0.1250 & 0.3600 & -0.2040 & 0.4339 \\
\hline LogAssets & -0.5134 & 0.7156 & 0.9691 & 0.7855 & 0.7416 & 0.8597 \\
\hline LogAge & -0.4182 & 1.7025 & 0.4733 & 1.7709 & 1.2297 & 1.7595 \\
\hline LogBeds & -2.0458 & 2.6356 & -2.5596 & 3.1221 & -4.6315 & 4.4460 \\
\hline IndTec & 1.6797 & 1.0885 & 1.1381 & 0.8385 & 1.2785 & 0.8602 \\
\hline Capital & -1.7721 & 2.0732 & $-3.3941^{* * *}$ & 2.0654 & $-4.6315^{* *}$ & 2.1134 \\
\hline Year 2005 & \multicolumn{2}{|c|}{ Reference } & \multicolumn{2}{|c|}{ Reference } & \multicolumn{2}{|c|}{ Reference } \\
\hline Year 2006 & 0.4267 & 1.2674 & 0.5391 & 1.0899 & -0.8286 & 1.1540 \\
\hline Year 2007 & 0.0766 & 1.4935 & -0.2272 & 1.3100 & $-2.3276^{*}$ & 1.3994 \\
\hline Year 2008 & -1.6188 & 1.4935 & -0.9503 & 1.3192 & $-2.4953^{*}$ & 1.4130 \\
\hline Year 2009 & -1.1418 & 1.5125 & -0.1168 & 1.3181 & -1.6629 & 1.4292 \\
\hline Year 2010 & $-4.6218^{* * *}$ & 1.5268 & $-4.3037^{* * *}$ & 1.3683 & $-4.8255^{* * *}$ & 1.4495 \\
\hline Year 2011 & $-4.4000^{* * *}$ & 1.5375 & $-3.4381^{* *}$ & 1.3983 & $-5.5105^{* * *}$ & 1.4860 \\
\hline Year 2012 & $-4.5462^{* * *}$ & 1.5875 & $-3.4491^{* *}$ & 1.4447 & $-5.2907^{* * *}$ & 1.5287 \\
\hline Specialty & \multicolumn{2}{|c|}{ Yes $^{\text {a }}$} & \multicolumn{2}{|l|}{ - } & \multicolumn{2}{|l|}{ Yes } \\
\hline AARR & \multicolumn{2}{|c|}{ Yes $^{a}$} & \multicolumn{2}{|l|}{ Yes } & \multicolumn{2}{|c|}{ Yes } \\
\hline Constant & $35.6673^{* * *}$ & 8.0163 & $21.1731^{* * *}$ & 7.9248 & $30.9253^{* * *}$ & 11.6115 \\
\hline No observations & \multicolumn{2}{|l|}{825} & \multicolumn{2}{|c|}{820} & \multicolumn{2}{|c|}{701} \\
\hline № hospitals & \multirow{2}{*}{\multicolumn{2}{|c|}{152}} & \multirow{2}{*}{\multicolumn{2}{|c|}{142}} & \multicolumn{2}{|c|}{122} \\
\hline \multicolumn{3}{|l|}{$R^{2}$} & & & & \\
\hline Within & \multicolumn{2}{|l|}{0.2783} & \multicolumn{2}{|l|}{0.2447} & \multicolumn{2}{|l|}{0.2773} \\
\hline Between & \multicolumn{2}{|l|}{0.3925} & 0.3550 & & 0.3884 & \\
\hline Overall & 0.3990 & & 0.3501 & & 0.3933 & \\
\hline Estimated rho & 0.4271 & & 0.4799 & & 0.4533 & \\
\hline$\%$ variance & & & & & & \\
\hline$\eta$ modified Bhargava et al. Durbin-Watson test & 1.3620 & & 1.2802 & & 1.2809 & \\
\hline
\end{tabular}

Variables: ROA: (EBIT/Total assets) $\mathrm{x} 100$; Insurers: Dummy $=1$ if the controlling shareholder is an insurance company; NoContSh: Dummy $=1$ if no shareholder has more than $50 \%$ of the ownership; Con-SS: Dummy $=1$ if the hospital has an accord with the Spanish public health system; Con-Cat: Dummy = 1 if the hospital has an accord with the Catalan public health system; Concession: Dummy $=1$ if the hospital is managed through an administrative concession; Leverage: Total debt/Total assets; GrowthOp: Intangible assets/Total assets; LogBeds: logarithm number of beds; LogAssets: logarithm assets; LogAge: logarithm number of years since founded; IndTec: Quantitative standardised index of technological equipment made with an analysis of principal components; Capital: Dummy $=1$ if hospital is located in provincial capital; Year: dummies $=1$ for each year from 2005 to 2012; Specialty: Dummies specialty (see Table A1 appendix); AARR: Dummies Autonomous Regions (see Table A2 appendix). $*^{*}, * * * *$ : significant to $10 \%, 5 \%$ and $1 \%$, respectively.

entry of venture capital funds as shareholders, and the positioning of insurance companies and banks, the latter abandoning positions at the beginning of the banking crisis and the subsequent bailouts. The changes point to a greater concentration of ownership in fewer hands, with a greater proportion of hospitals in the hands of a controlling shareholder, and a shift of hospital ownership from banks and insurance companies to businesses, individuals and families. This dynamic supports the arguments of Shleifer and Vishny (1986) concerning the continuity of ownership structures. They suggest that once a significant block of shares has been assembled, it is unlikely to 
be dispersed, and they conclude that significant holdings tend to be transmitted intact. Köke (1999) documents for Germany a great stability in the ownership structure of most unlisted companies, a stability seen only in $25 \%$ of publicly traded companies.

In Spain, private for-profit hospitals attain their goals, that is, they are profitable, even in years of economic crisis, although their profitability slows somewhat after 2009, when there were across-the-board cuts in government spending that also affected hospitals with accords with the public health system. In any case, official aggregate figures show that during the economic crisis, private health spending in Spain increased 7.7\%, whereas public spending declined 9\% (MSSSI 2014).

According to our results, hospitals belonging to health insurance companies are significantly less profitable than are those belonging to businesses, individuals, families or banks and other financial enterprises. Moreover, we provide support for the tunnelling hypothesis because the insurance companies can be using internal transfer mechanisms and internal exchange prices that favour the original insurance business and principal enterprise. In addition, our results show that hospitals vertically integrated with insurance companies have more expenses than revenues compared with other hospitals. This point can be explained by the fact that, although there is an increase in the revenues derived from the growth in the number of patients, the revenues per patient might be lower due to the low prices that the insurance company imposes on the hospital. These results allow concluding that the vertical integration strategy reduces hospital performance, offering an alternative explanation for the rent seeking derived from the tunnelling effect.

The absence of previous studies that analyse the relationship of ownership and performance of private hospitals precludes comparing our findings with those of others. There are studies for Germany that show that private hospitals have better financial performance (measured by probability of non-payment) than do public ones (Augurzky, Engel, Schmidt, \& Schwierz, 2009) and are more efficient in financial benefits (Herr, Schmitz, \& Augurzky, 2011, for a sample of 541 German hospitals 2002-2006).

Studies exist that have analysed the effect of insurance companies in particular or 'pressure-sensitive' institutional investors in general on different types of businesses, particularly publicly traded ones. Rose (2007), for instance, found for Denmark that ownership by insurance companies improved the performance of publicly traded companies. For Finland, Bhattacharya and Graham (2007) found that institutions that had business relationships with firms in which they were shareholders negatively affected the firm's performance and explained this effect by the fact that the institutions did not want to have conflicts of interest with management, which might lose the business relationships. Elyasiani and Jia (2010) find that both pressure-sensitive and pressure-insensitive institutional investors have a positive effect on publicly traded US companies, although this effect is smaller in the case of pressure-sensitive institutions, which suggests that pressure-insensitive institutions are more effective in controlling management. For Spain, Ruiz and Santana (2011) explain the negative effect of banks that are controlling shareholders on publicly traded firms by the private gain that the banks can extract through their business relationships with the firms in question. The empirical evidence is inconclusive concerning the effect on performance of institutional investors doing business with the companies they control, indicating the importance of distinguishing between particular institutional contexts (Aggarwal, Erel, Ferreiras, \& 
Matos, 2011; Gillan \& Starks, 2003; Ruiz \& Santana, 2011). Evidence for this point is the behaviour of these insurance companies, which is characterised by extracting income for the dominant enterprise to the detriment of the hospital's performance.

The results obtained also indicate that, for private hospitals, an agreement with the NHS to provide services to publically insured persons improves the hospitals' returns on assets by approximately 4 percentage points. In this sense, we also find feasible public policy implications of this finding with respect to the agreement policies. On the one hand, the balances and cost structures of hospitals that belong to insurance companies should not serve as a basis for informing possible public-private collaboration accords or health delivery agreements. This implication is particularly relevant for the periodic revisions of health insurance policies of civil servants. In Spain, civil servants and their families, who compose approximately $4.1 \%$ of the population, have a system of public insurance that permits the user to choose an insurance company. Most of them choose private companies, and these users from the civil service compose approximately $19 \%$ of all health policyholders serviced by private companies in Spain. On the other hand, the study reveals the importance of knowing the costs of the services provided by hospitals, which would give arguments in order to negotiate the prices of services with both the NHS and insurance companies.

In contrast to other studies, this one found no systematic differences among the types of hospitals, apart from the higher return on assets of psychiatric hospitals. Other studies found that 'specialty' hospitals, which generally belong to doctors, could achieve lower costs without sacrificing quality (Barro, Huckman, \& Kessler, 2006) or, in contrast, were less cost-efficient than general hospitals (Carey, Burgess, \& Young, 2008).

The main strengths of this study are that, contrary to the mainstream literature, we focus on unlisted for-profit hospitals and use a large panel covering a period of economic downturn. We also exploited a unique, rich database with information on the existence of a dominant shareholder and the type of ownership.

Our study has one limitation about the sample size. One-half of the potential observations are missing due to the absence of financial and/or ownership information. That omission exists because the firms in the sample are unlisted; therefore, they are not forced to provide information about their shareholders.

In summary, this study sheds light on profitability and ownership in hospitals. We show that the identity of controlling shareholder is relevant for managers, healthcare professionals, patients and policy makers. Specifically, hospitals controlled by insurance companies are less profitable due to different mechanisms related to tunnelling and vertical integration that influence profitability ratios and their components, affecting activity, costs and prices.

\section{Notes}

1. UNESPA Social Report 2015 http://www.unespa.es/adjuntos/fichero_4174_20160602.pdf.

2. Ferreira and Matos (2008) call these groups 'grey' and 'independent' investors, respectively.

3. Other tunnelling practices include transfer of assets from a firm to its controlling shareholder at nonmarket prices or loan guarantees using the firm's assets as collateral (Johnson et al., 2000). 
4. Quoted in Song (2015).

5. Other types of vertical integration in the health services industry are between hospitals and physicians or between different stages of health care provisioning.

6. Induced demand occurs when a physician suggests to the patient a benefit that is not medically necessary or one more expensive than another that achieves the same result, which represents an agency problem between the insurer and the service provider.

7. The revenues from conciertos with the Public Health System represent $26.3 \%$, from private clients 9.2\%, and 2.2\% from other clients (Barrubes y Mellado, 2011).

8. Tienman et al. (2012) review the empirical studies on the relationship between ownership and efficiency, distinguishing between technical and expense efficiency in the United States and Germany. Most of the studies focus on the differences between private and public hospitals (profit or non-for-profit).

9. Gapenski et al. (1993); Wang et al. (2001); Shen et al. (2007); Büchner et al. (2016).

10. Among the studies analysing the relationship between ownership (public versus private) and operational efficiency of hospitals are Chang, Cheng, and Das (2004) and Ding (2014).

11. Gapenski et al. (1993), Ehreth (1994), Clement et al. (1997), Wang et al. (2001), Shen et al. (2007), Herr et al. (2011), Augurzky et al. (2009), Ozcan et al. (1992) and Ding (2014).

12. As they report only critical values for some specific $\mathrm{N}, \mathrm{T}$ and $\mathrm{K}$, we use the closest values $\mathrm{N}=100, \mathrm{~T}=6$, and $\mathrm{K}=9$. The critical values are $\mathrm{dL}=1.839$ and $\mathrm{du}=1.902$.

13. This statement is true for the hospitals belonging to the group SANITAS.

14. An example is the hospitals linked to the health insurance company Adeslas. Both hospitals and insurance company initially had as majority shareholder la Caixa, which subsequently sold its stake in hospitals to the Vithas group.

15. The table data are logarithmic.

16. The reference year in models 7 and 9 (Table 6) is 2012, and the year 2005 has been eliminated because lagged variables have been considered. Consequently, the signs change regarding the model 1 . The same happens in models 10 and 12 (Table 7).

17. This method is based on the distance between observations and iteratively proceeds to detect the extreme values, in our case 90 observations. Among the studies that have applied this method to debug outliers are Dargenidou and McLeay (2010) and BonaSanchez, Perez-Aleman, and Santana-Martin (2011).

18. Available upon request from the corresponding author.

\section{Disclosure statement}

No potential conflict of interest was reported by the authors.

\section{ORCID}

Inmaculada Aguiar-Díaz (iD http://orcid.org/0000-0002-2809-2520

María Victoria Ruiz-Mallorquí (D) http://orcid.org/0000-0002-9179-9342

Beatriz González López-Valcárcel (i) http://orcid.org/0000-0002-4312-5378

\section{References}

Aggarwal, R., Erel, I., Ferreiras, M., \& Matos, P. (2011). Does governance travel around the world? Evidence from institutional investors. Journal of Financial Economics, 100, 154-181.

Almazan, A., Hartzell, J. C., \& Starks, L. T. (2005). Active institutional shareholders and costs of monitoring: Evidence from executive compensation. Financial Management, 34(4), 5-34.

Anderson, R. C., \& Reeb, D. M. (2003). Founding-family ownership and firm performance: Evidence from the S\&P 500. The Journal of Finance, 58(3), 1301-1328. 
Andres, C. (2008). Large shareholders and firm performance-An empirical examination of founding-family ownership. Journal of Corporate Finance, 14(4), 431-445.

Arosa, B., Iturralde, T., \& Maseda, A. (2010). Ownership structure and firm performance in nonlisted firms: Evidence from Spain. Journal of Family Business Strategy, 1(2), 88-96.

Augurzky, B., Engel, D., Schmidt, C. M., \& Schwierz, C. (2009). Ownership and financial performance in the German hospital sector. Ruhr economic papers, p. 123. Retrieved from http://hdl.handle.net/10419/29946.

Bae, K. H., Kang, J. K., \& Kim, J. M. (2002). Tunneling or value added? Evidence from mergers by Korean business groups. The Journal of Finance, 57(6), 2695-2740.

Balakrishnan, R., Eldenburg, L., Krishnan, R., \& Soderstrom, N. (2010). The influence of institutional constraints on outsourcing. Journal of Accounting Research, 48(4), 767-794.

Baltagi, B. H., \& Wu, P. X. (1999). Unequally spaced panel data regressions with AR (1) disturbances. Econometric Theory, 15, 814-823.

Baranes, E., \& Bardey, D. (2015). Competition between health maintenance organizations and nonintegrated health insurance companies in health insurance markets. Health Economics Review, 5(1), 36.

Barclay, M. J., Holderness, C., \& Pontiff, J. (1993). Private benefits from block ownership and discounts on closed-end funds. Journal of Financial Economics, 33, 263-291.

Barro, J., Huckman, R., \& Kessler, D. (2006). The effects of cardiac specialty hospitals on the cost and quality of medical care. Journal of Health Economics, 25(4), 702-721.

Barrubés, J., \& Mellado, J. C. (2011). El Mercado español de clínicas privadas con finalidad lucrativa: Realidades y Tendencias. Antares Consulting. Retrieved from http://www.antaresconsulting.com/uploads/TPublicaciones/2aa0c8ec2defa32255ba104f1f0faf3d1a16a4a3.pdf.

Bertrand, M., Mehta, P., \& Mullainathan, S. (2002, February). Ferreting out tunneling: An application to Indian business groups (No. w7952). The Quarterly Journal of Economics, 117 (1), 121-148.

Bhargava, A., Franzini, L., \& Narendranathan, W. (1982). Serial correlation and the fixed effects model. Review of Economic Studies, 49, 533-549.

Bhattacharya, P. S., \& Graham, M. (2007). Institutional ownership and firm performance: Evidence from Finland. Working Paper SSRN 1000092. Retrieved from http://papers.ssrn. com/sol3/papers.cfm?abstract_id=1000092.

Bona, C., Pérez, J., \& Santana, D. J. (2013). Dominant institutional control and earnings informativeness. Spanish. Journal of Finance and Accounting, XLII(159), 371-394.

Bona-Sanchez, C., Perez-Aleman, J., \& Santana-Martin, D. J. (2011). Ultimate ownership and earnings conservatism. European Accounting Review, 20(1), 57-80.

Borokhovich, K. A., Brunarski, K., Harman, Y. S., \& Parrino, R. (2006). Variation in the monitoring incentives of outside stockholders. The Journal of Law and Economics, 49, 651-680.

Brickley, J., Lease, R., \& Smith, C. (1988). Ownership structure and voting antitakeover amendment. Journal of Financial Economic,S, 20, 267-292.

Büchner, V. A., Hinz, V., \& Schreyögg, J. (2016). Health systems: Changes in hospital efficiency and profitability. Health Care Management Science, 19(2), 130-143.

Burns, L. R. (1990). The transformation of the American hospital: From community institution towards business enterprise. Comparative Social Research, 12, 77-112.

Caers, R., Bois, C.D., Jegers, M., Gieter, S.D., Schepers, C. and Pepermans R. (2006). PrincipalAgent relationships on the stewardship-agency axis. Nonprofit managament and Leadership, 17 (1), 25-47.

Cardinaels, E., \& Soderstrom, N. (2013). Managing in a complex world: Accounting and governance choices in hospitals. European Accounting Review, 22(4), 647-684.

Carey, K., Burgess, J. F., \& Young, G. J. (2008). Specialty and full-service hospitals: A comparative cost analysis. Health Services Research, 43(5p2), 1869-1887.

Chang, H., Cheng, M., \& Das, S. (2004). Hospital ownership and operating efficiency: Evidence from Taiwan. European Journal of Operational Research, 159, 513-527.

Chen, X., Harford, J., \& Li, K. (2007). Monitoring: Which institutions matter? Journal of Financial Economics, 86, 279-305. 
Ciliberto, F., \& Dranove, D. (2006). The effect of physician-hospital affiliations on hospital prices in California. Journal of Health Economics, 25(1), 29-38.

Claessens, S., Djankov, S., Fan, J. P. H., \& Lang, L. H. P. (2002). Disentangling the incentive and entrenchment effects of large shareholdings. The Journal of Finance, 57(6), 2741-2771.

Clement, J. P., McCue, M. J., Luke, R. D., Bramble, J. D., Rossiter, L. F., Ozcan, Y. A., \& Pai, C. W. (1997). Strategic hospital alliances: Impact on financial performance. Health Affairs, 16(6), 193-203.

Cornett, M. M., Marcus, A. J., Saunders, A., \& Tehranian, H. (2007). The impact of institutional ownership on corporate operating performance. Journal of Banking and Finance, 31, 17711794.

Cuervo, A. (2002). Corporate governance mechanisms: A plea for less code of good governance and more market control. Corporate Governance: An International Review, 10, 84-93.

Cutler, D. M., McClellan, M., \& Newhouse, J. P. (2000). How does managed care do it? The RAND Journal of Economics, 31(3), 526-548.

Dai, N. (2007). Does investor identity matter? An empirical examination of investments by venture capital funds and hedge funds in PIPEs. Journal of Corporate Finance, 13(4), 538563.

Dargenidou, C., \& McLeay, S. (2010). The impact of introducing estimates of the future on international comparability in earnings expectations. European Accounting Review, 19(3), 511534.

De Andrés Alonso, P., Palenzuela, V. A., \& Gaite, F. T. (2010). The bank: Controller or predator in the governance of nonfinancial firms? Investment Management and Financial Innovations, 7 (1), 24-36.

De la Hoz, M. C., \& Pombo, C. (2016). Institutional investor heterogeneity and firm valuation: evidence from Latin America. Emerging Markets Review, 26, 197-221.

Ding, D. X. (2014). The effect of experience, ownership and focus on productive efficiency: A longitudinal study of U.S. hospitals. Journal of Operations Management, 32(1-2), 1-14.

Duggal, R., \& Millar, J. (1994). Institutional investors, antitakeover defenses and success of hostile takeover bids. The Quarterly Journal of Economics, 34, 387-402.

Ehreth, J. (1994). The development and evaluation of hospital performance measures for policy analysis. Medical Care, 32(6), 568-587.

Eldenburg, L., Hermalin, B. E., Weisbach, M. S., \& Wosinska, M. (2004). Governance, performance objectives and organizational form: Evidence from hospitals. Journal of Corporate Finance, 10(4), 527-548.

Elyasiani, E., \& Jia, J. J. (2010). Distribution of institutional ownership and corporate firm performance. Journal of Banking and Finance, 34(3), 606-620.

Faccio, L., \& Lang, L. (2002). The ultimate ownership of Western European corporations. Journal of Financial Economics, 65, 365-395.

Ferreira, M. A., \& Matos, P. (2008). The colors of investors' money: The role of institutional investors around the world. Journal of Financial Economics, 88, 499-533.

Friedman, E., Johnson, S., \& Mitton, T. (2003). Propping and tunneling. Journal of Comparative Economics, 31(4), 732-750.

Gal-Or, E. (1997). Exclusionary equilibria in health care markets. Journal of Economics and Management Strategy, 6(1), 5-42.

Gapenski, L. C., Vogel, W. B., \& Langland-Orban, B. (1993). The determinants of hospital profitability. Hospital and Health Services Administration, 38(1), 63-80.

Gillan, S. L., \& Starks, L. T. (2003). Corporate governance, corporate ownership, and the role of institutional investors, a global perspective. Journal of Applied Finance, 13, 4-22.

Gorton, G., \& Smith, F. (2000). Universal banking and the performance of German firms. Journal of Financial Economics, 58, 29-80.

Gugler, K. (2013). The determinants of rent extraction in the parent-subsidiary relation. Empirica, 40(2), 343-362.

Hadi, A. (1992). Identifying multiple outliers in multivariate data. Journal of the Royal Statistical Society, Series (B), 54, 761-771. 
Hadi, A. (1994). A modification of a method for the detection of outliers in multivariate samples. Journal of the Royal Statistical Society, Series (B), 56, 393-396.

Herr, A., Schmitz, H., \& Augurzky, B. (2011). Profit efficiency and ownership of German hospitals. Health Economics, 20, 660-674.

Hoshi, T., Kashyap, A., \& Scharfstem, D. (1993). The choice between public and private debt: An analysis of post-regulation corporate financing Japan. Working paper, NBER. Retrieved from http://www.nber.org/papers/w4421.

Hsu, S. H. (2011). Cost information and pricing: Empirical evidence. Contemporary Accounting Research, 28, 554-579.

Jeurissen, P. (2010). A comparative and longitudinal study of the for-profit hospital sector in four Western countries (Doctoral Thesis). Erasmus University, Rotterdam. Retrieved from http:// repub.eur.nl/pub/40394/.

Johnson, S., La Porta, R., Lopez-de-Silanes, F., \& Shleifer, A. (2000). Tunneling. The American economic review 90(2), 22-27

Klein, B., Crawford, R., \& Alchian, A. (1978). Vertical integration, appropriable rents, and the competitive contracting process. Journal of Law and Economics, 21, 297-326.

Klenk, T. (2011). Ownership change and the rise of a for-profit hospital industry in Germany. Policy Studies, 32(3), 263-275.

Köke, F. J. (1999). New evidence on ownership structures in Germany. Working Paper SSRN 198928. Retrieved from http://papers.ssrn.com/sol3/papers.cfm?abstract_id=198929.

La Porta, R., Lopez-de-Silanes, F., \& Shleifer, A. (1999). Corporate ownership around the world. The Journal of Finance, 54(2), 471-517.

Lachmann, M., Trapp, R., \& Wenger, F. (2016). Performance measurement and compensation practices in hospitals: An empirical analysis in consideration of ownerships types. European Accounting Review, 25(4), 661-686.

López de Foronda, O., López-Iturriaga, F., \& Santamaría-Mariscal, M. (2007). Ownership structure, sharing of control and legal framework: International evidence. Corporate Governance: An International Review, 15(6), 1130-1143.

Mapfre, F. (2012. El mercado español de seguros en 2012. Retrieved from http://www.fundacion mapfre.org/fundacion/es_es/seguro-prevision-social/investigacion/informe-mercados-asegura dores-centro-estudios/default.jsp

MSSSI Ministerio de Sanidad Servicios Sociales e Igualdad (2014, Agosto). Sistema de Cuentas de Salud. Principales Resultados. Retrieved from http://www.msssi.gob.es/estadEstudios/estadisti cas/sisInfSanSNS/pdf/SCSprincipalesResultados.pdf

Nain, A., \& Yao, T. (2013). Mutual fund skill and the performance of corporate acquirers. Journal of Financial Economics, 110, 437-456.

Narine, L., Pink, G., \& Leatt, P. (1996). Prediction of the financial performance of Ontario hospitals: A test of environmental determinist and adaptationist perspectives. Health Services Management Research, 9(3), 137-155.

National Hospital Catalogue (NHC) Ministerio de Sanidad, Servicios Sociales e Igualdad. Retrieved from http://www.msssi.gob.es/ciudadanos/prestaciones/centrosServiciosSNS/hospi tales/home.htm

Ozcan, Y. A., Luke, R. D., \& Haksever, C. (1992). Ownership and organizational performance: A comparison of technical efficiency across hospital types. Medical Care, 30, 781-794.

Robinson, J. C. (1999). The corporate practice of medicine. California: University of California Press.

Robinson, J. C., \& Casalino, L. P. (1996). Vertical integration and organizational networks in health care. Health Affairs, 15(1), 7-22.

Rose, C. (2007). Can institutional investors fix the corporate governance problem? Some Danish evidence. Journal of Management \& Governance, 11(4), 405-428.

Ruiz, M. V., \& Santana, D. J. (2009). Ultimate institutional owner and takeover defenses in the controlling versus minority shareholders context. Corporate Governance: An International Review, 17(2), 238-254. 
Ruiz, M. V., \& Santana, D. J. (2011). Dominant institutional owners and firm value. Journal of Banking and Finance, 35(1), 118-129.

SABI. Sistema de Análisis de Balances Ibéricos, Database Informa, Bureau van Dick.

Santos, J. A., \& Rumble, A. S. (2006). The American keiretsu and universal banks: Investing, voting and sitting on nonfinancials' corporate boards. Journal of Financial Economics, 80(2), 419-454.

Serrasqueiro, Z., \& Caetano, A. (2015). Trade-off theory versus pecking order theory: Capital structure decisions in a peripheral region of Portugal. Journal of Business Economics and Management, 16(2), 445-466.

Shen, Y.-C. (2003). Changes in hospital performance after ownership conversions. Inquiry, 40(3), 217-234.

Shen, Y. C., Eggleston, K., Lau, J., \& Schmid, C. H. (2007). Hospital ownership and financial performance: What explains the different findings in the empirical literature? Inquiry, 44, 4168.

Shleifer, A., \& Vishny, R. (1986). Large shareholders and corporate control. Journal of Political Economy, 94(3, Part 1), 461-488.

Shleifer, A., \& Vishny, R. W. (1997). A survey of corporate governance. The Journal of Finance, 52(2), 737-783.

Song, X. (2015). Monitoring or tunneling by large shareholders: Evidence from China private listed companies. China Finance Review International, 5(2), 187-211.

Thomsen, S., \& Pedersen, T. (2000). Ownership structure and economic performance in the largest European companies. Strategic Management Journal, 21, 689-705.

Tiemann, O., Schereyogg, J., \& Busse, R. (2012). Hospital ownership and efficiency: A review of studies with particular focus on Germany. Health Policy, 104, 163-171.

Tirole, J. (1989). The theory of industrial organization. Cambridge: MIT Press.

Villalonga, B., \& Amit, R. (2006). How do family ownership, control and management affect firm value? Journal of Financial Economics, 80(2), 385-417.

Wang, B. B., Wan, T. T., Clement, J., \& Begun, J. (2001). Managed care, vertical integration strategies and hospital performance. Health Care Management Science, 4(3), 181-191.

Weinstein, D., \& Yafeh, Y. (1998). On the cost of a bank-centered financial system: Evidence from the changing main bank relations in Japan. The Journal of Finance, 53, 635-672.

Wilcox-Gok, V. (2002). The effects of for-profit status and system membership on the financial performance of hospitals. Applied Economics, 34(4), 479-489. 


\section{Appendix}

Table A1. Description of variables.

\begin{tabular}{|c|c|c|}
\hline Name & Calculation & Literature \\
\hline \multicolumn{3}{|c|}{ Dependent variables } \\
\hline $\begin{array}{l}\text { Profitability: } \\
\text { ROA, ROA_EBITDA }\end{array}$ & $\begin{array}{l}\text { (EBIT/Total assets) } \times 100 \\
\text { (EBITDA/Total assets) } \times 100\end{array}$ & $\begin{array}{l}\text { Gapenski, Vogel, and Langland-Orban (1993), } \\
\text { Wang, Wan, Clement, and Begun (2001), } \\
\text { Shen et al. (2007); Büchner, Hinz, and } \\
\text { Schreyögg (2016) }\end{array}$ \\
\hline $\begin{array}{l}\text { Revenues } \\
\text { Cost efficiency } \\
\text { (Cost_Efi) }\end{array}$ & $\begin{array}{l}\text { (Revenues/Total assets) } \times 100 \\
\text { (Operating cost/total assets) } \times 100\end{array}$ & \\
\hline $\begin{array}{l}\text { Operating Margin } \\
\text { (Op-Margin }\end{array}$ & (EBITDA/Operating revenues) $\times 100$ & $\begin{array}{l}\text { Gapenski et al. (1993), Wang et al. (2001), Shen } \\
\text { et al. (2007); Büchner et al. (2016) }\end{array}$ \\
\hline \multicolumn{3}{|c|}{ Explanatory variables $^{\mathrm{a}}$} \\
\hline $\begin{array}{l}\text { No controlling } \\
\text { shareholder No- } \\
\text { ContSh }\end{array}$ & \multicolumn{2}{|c|}{ Dummy $=1$ if no shareholder has more than $50 \%$ of the ownership } \\
\hline $\begin{array}{l}\text { Insurance companies: } \\
\text { Insurers }\end{array}$ & \multicolumn{2}{|c|}{ Dummy $=1$ if the controlling shareholder is an insurance company } \\
\hline $\begin{array}{l}\text { Banks and financial } \\
\text { firms: }\end{array}$ & \multicolumn{2}{|c|}{ Dummy $=1$ if the controlling shareholder is a financial enterprise (bank, pension fund, ....) } \\
\hline Banks & & \\
\hline $\begin{array}{l}\text { Enterprises: } \\
\quad \text { Enterprises }\end{array}$ & \multicolumn{2}{|c|}{ Dummy $=1$ if the controlling shareholder is a non-financial enterprise } \\
\hline $\begin{array}{l}\text { Individuals or } \\
\text { families: Families }\end{array}$ & \multicolumn{2}{|c|}{ Dummy $=1$ if the controlling shareholder is one or various individuals or a family } \\
\hline \multicolumn{3}{|c|}{ Control variables } \\
\hline $\begin{array}{l}\text { Accord (Concierto) } \\
\text { Con-SS }\end{array}$ & \multicolumn{2}{|c|}{ Dummy $=1$ if the hospital has an accord with the Spanish public health system } \\
\hline Con-Cat & \multirow{2}{*}{\multicolumn{2}{|c|}{$\begin{array}{l}\text { Dummy }=1 \text { if the hospital has an accord with the Catalan public health system } \\
\text { Dummy }=1 \text { if the hospital is managed through an administrative concession }\end{array}$}} \\
\hline Concession & & \\
\hline Leverage & Total debt/Total assets & $\begin{array}{l}\text { Gapenski et al. (1993); Arosa, Iturralde, and } \\
\text { Maseda (2010) }\end{array}$ \\
\hline Growth & Intangible assets/Total assets & Serrasqueiro and Caetano (2015) \\
\hline Opportunities & $\begin{array}{l}\text { Revenues variation }= \\
\left(\text { revenues }_{\mathrm{t}} \text {-revenues }{ }_{\mathrm{t}-1} \text { )/revenues }{ }_{\mathrm{t}-1}\right.\end{array}$ & Arosa et al. (2010) \\
\hline Size & logarithm number of beds & Gapenski et al. (1993), Ozcan, Luke, and \\
\hline $\begin{array}{l}\text { LogBeds } \\
\text { LogAssets }\end{array}$ & logarithm assets & $\begin{array}{l}\text { Haksever (1992), Ehreth (1994), Clement } \\
\text { et al. (1997), Wilcox-Gok (2002),Shen (2003), } \\
\text { Herr et al. (2011), Augurzky et al. (2009), } \\
\text { Ding (2014) }\end{array}$ \\
\hline Age: Age & Number of years since founded & Gapenski et al. (1993), Ding (2014) \\
\hline Capital: Capital & $\begin{array}{l}\text { Dummy }=1 \text { if hospital is located in } \\
\text { provincial capital }\end{array}$ & Ehreth (1994), Herr et al. (2011) \\
\hline $\begin{array}{l}\text { Index of technology: } \\
\text { IndTec }\end{array}$ & $\begin{array}{l}\text { Quantitative standardised index of } \\
\text { technological equipment made with an } \\
\text { analysis of principal components }\end{array}$ & Narine, Pink, and Leatt (1996) \\
\hline Year & $\begin{array}{l}\text { Dummies }=1 \text { from each year from } 2005 \text { to } \\
2012\end{array}$ & $\begin{array}{l}\text { Wilcox-Gok (2002), Herr et al. (2011), Ding } \\
\text { (2014) }\end{array}$ \\
\hline Specialty: Specialty & Dummies specialty (see Table A2 Appendix) & $\begin{array}{l}\text { Gapenski et al. (1993), Ozcan et al. (1992), } \\
\text { Wilcox-Gok (2002) }\end{array}$ \\
\hline $\begin{array}{l}\text { Autonomous Region: } \\
\boldsymbol{A A R \boldsymbol { R }}\end{array}$ & $\begin{array}{l}\text { Dummies Autonomous Regions (see } \\
\text { Table A2 Appendix) }\end{array}$ & $\begin{array}{l}\text { Gapenski et al. (1993), Ozcan et al. (1992), } \\
\text { Shen (2003), Herr et al. (2011), Augurzky } \\
\text { et al. (2009), Ding (2014) }\end{array}$ \\
\hline Population & Number of inhabitants in the AARR & \\
\hline $\begin{array}{l}\text { Per capita income: } \\
\text { GDPpC }\end{array}$ & Per capita income in the AARR & \\
\hline
\end{tabular}

${ }^{a}$ Previous studies considered public hospitals, private for-profit and private non-profit hospitals

b This variable is a particular aspect of the Spanish health system; we have not found parallels in other countries or previous studies.

Sources: dependent, explanatory and financial variables: SABl; non-financial control variables: NHC. 
Table A2. Distribution of the sample by specialty and location.

\begin{tabular}{lclr}
\hline Specialty & $(\%)$ & Autonomous Region & $(\%)$ \\
\hline General & 71.66 & Andalusia & 15.96 \\
Surgical & 9.61 & Aragon & 2.38 \\
Maternity and Paediatric & 0.99 & Asturias & 2.58 \\
Psychiatric & 6.54 & Baleares & 3.57 \\
Ophthalmology or Ears, Nose and Throat & 0.89 & Canarias & 6.64 \\
Traumatology and/or Rehabilitation & 0.89 & Cantabria & 0.79 \\
Psychophysical Rehabilitation & 1.09 & Castilla-La Mancha & 3.27 \\
Geriatric or long-term & 5.95 & Castilla y León & 3.96 \\
Other specialties & 2.38 & Catalonia & 17.44 \\
& & Comunidad Valenciana & 11.50 \\
& & Galicia & 9.32 \\
& & Madrid & 9.81 \\
& & Murcia & 4.56 \\
& & Navarre & 0.99 \\
& & Basque Country & 6.14 \\
& & La Rioja & 1.09 \\
\hline
\end{tabular}




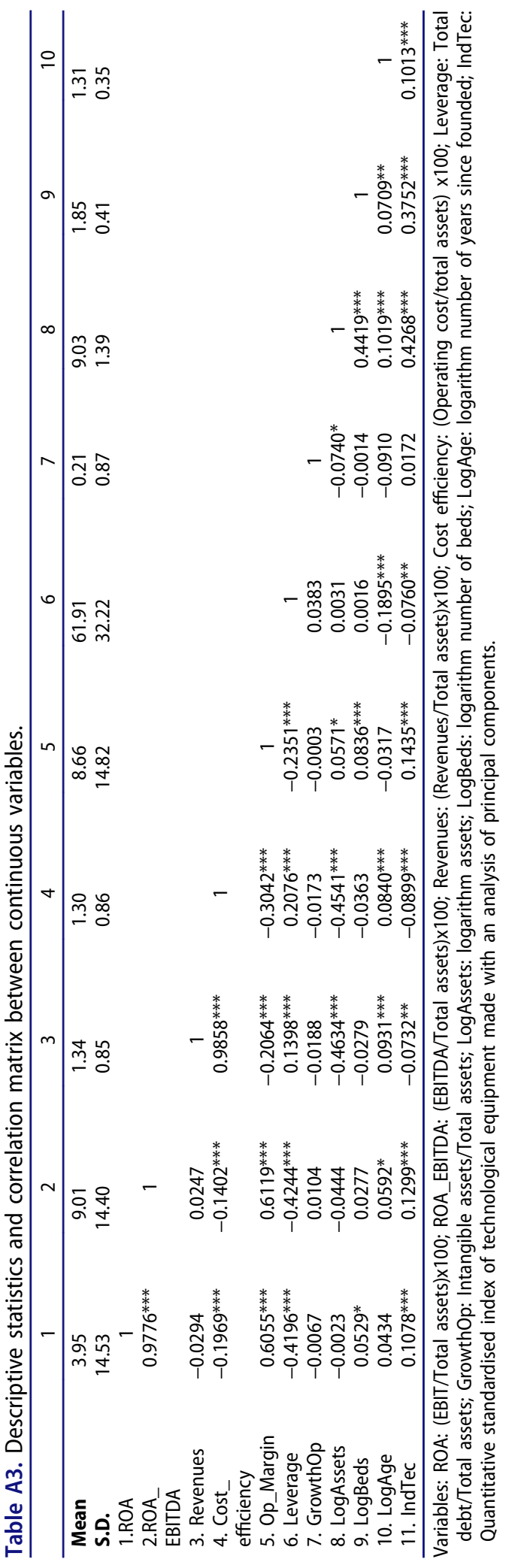


Table A4. Ownership and performance of private for-profit hospitals in Spain 2005-2012 Estimation: panel regression models Results: Specialty and Autonomous region.

\begin{tabular}{|c|c|c|c|c|}
\hline \multirow{2}{*}{$\frac{\text { Models }}{\text { Specialty }}$} & \multicolumn{2}{|c|}{ (1) } & \multicolumn{2}{|c|}{ (6) } \\
\hline & $\beta$ & S.E. & $\beta$ & S.E. \\
\hline General & \multicolumn{2}{|c|}{ Reference } & \multicolumn{2}{|c|}{ Reference } \\
\hline Surgical & -1.2628 & 2.7145 & -0.1431 & 3.0674 \\
\hline Maternity and Paediatric & -4.7867 & 7.2721 & 1.1934 & 8.2526 \\
\hline Psychiatric & $5.2389 *$ & 2.9898 & 3.3353 & 3.3919 \\
\hline Ophthalmology or Ear Nose and Throat & -1.0621 & 6.7598 & 2.7202 & 7.5802 \\
\hline Traumatology and/or Rehabilitation & 7.1117 & 6.4827 & 8.0255 & 7.1902 \\
\hline Psychophysical Rehabilitation & 10.9886 & 7.6464 & 13.5921 & 8.6846 \\
\hline Geriatric or long-term & 4.6094 & 2.9692 & $10.1595^{* * *}$ & 3.3381 \\
\hline Other specialties & -1.8962 & 4.6833 & -1.5735 & 5.3145 \\
\hline \multicolumn{5}{|l|}{ Autonomous region } \\
\hline Andalusia & \multicolumn{2}{|c|}{ Reference } & \multicolumn{2}{|c|}{ Reference } \\
\hline Aragon & -3.7883 & 5.5058 & -10.2461 & 6.2617 \\
\hline Asturias & -2.0793 & 4.9584 & 6.3093 & 5.6299 \\
\hline Baleares & -6.4961 & 4.2254 & $-15.1647^{* * *}$ & 4.8021 \\
\hline Canarias & $-6.9222^{* *}$ & 3.3692 & $-8.8556^{* *}$ & 3.8246 \\
\hline Cantabria & -3.0411 & 9.5553 & -9.0812 & 10.9111 \\
\hline Castilla-La Mancha & $-9.2075^{* *}$ & 4.6164 & $-12.5490^{* *}$ & 5.2373 \\
\hline Castilla y León & $-8.0048^{* *}$ & 3.9940 & -3.0582 & 4.5262 \\
\hline Catalonia & 1.5069 & 2.7558 & $-5.2068^{*}$ & 3.1315 \\
\hline Comunidad Valenciana & 1.3761 & 3.0267 & -1.5262 & 3.4443 \\
\hline Galicia & -0.7873 & 3.2231 & -4.2332 & 3.6629 \\
\hline Madrid & $-6.5888^{* *}$ & 3.1578 & $-9.4548^{* * *}$ & 3.5924 \\
\hline Murcia & 1.6743 & 4.1154 & -0.3680 & 4.6854 \\
\hline Navarre & -6.3335 & 7.2983 & -3.1832 & 8.2828 \\
\hline Basque Country & -2.0589 & 3.5568 & -0.7987 & 4.0466 \\
\hline La Rioja & $19.5456^{* * *}$ & 6.9703 & 4.1121 & 7.9414 \\
\hline
\end{tabular}

${ }^{*},{ }^{* *},{ }^{* * *}$ : significant to $10 \%, 5 \%$ and $1 \%$, respectively. 


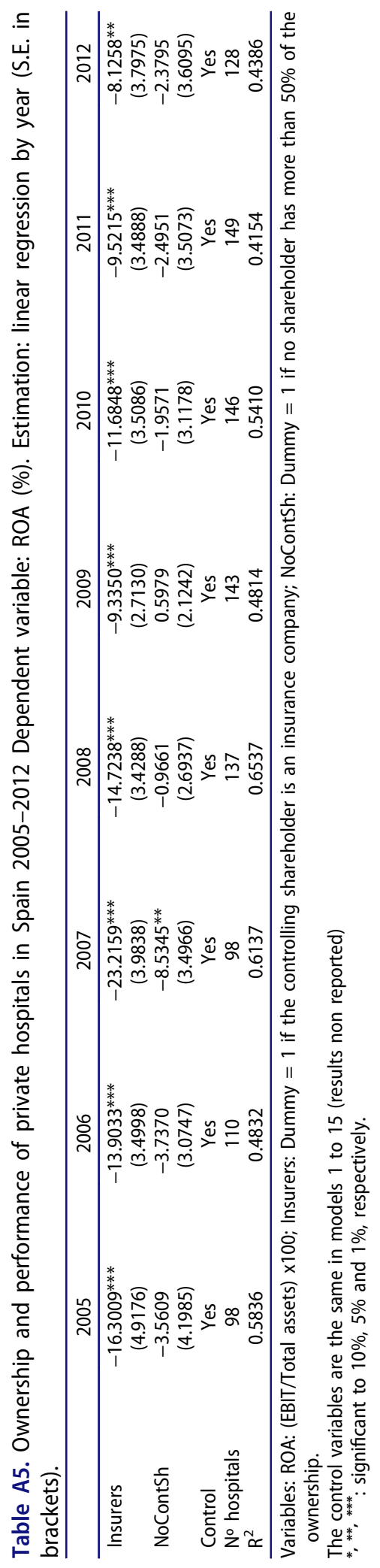

